\title{
BADANIA NAD NOWYM TESTAMENTEM W „COLLECTANEA THEOLOGICA” 1920-2020
}

Badania nad Nowym Testamentem w „Collectanea Theologica” w okresie stu lat istnienia tego czasopisma (1920-2020) można podzielić na kilka etapów. Cezury między nimi nie zawsze mają charakter wyraźny, gdyż pewne zjawiska w tej dziedzinie narastały i zanikały stopniowo w dłuższym okresie. Zaproponowana w niniejszym artykule periodyzacja ma jednak pomóc wychwycić elementy charakterystyczne dla danego okresu, by lepiej uzmysłowić sobie przemiany, jakim podlegały badania nad Nowym Testamentem w długiej i skomplikowanej historii istnienia czasopisma.

\section{Ambitne przedwojenne początki (1920-1939)}

Czasopismo pod nazwą „Przegląd Teologiczny” (dalej: PT) zaczęto wydawać we Lwowie jako kwartalnik teologiczny od I kwartału 1920 r. W pierwszych numerach „Przeglądu Teologicznego”, zwłaszcza w latach 1921-1924, kwestie związane z badaniami nad Nowym Testamentem zajmują poczesne miejsce.

Już w pierwszym zeszycie nowego czasopisma pojawia się recenzja niemieckojęzycznej książki ks. Józefa Wrzoła, Polaka ze Śląska, dotyczącej autentyczności Drugiego Listu do Tesaloniczan. Recenzja ta, napisana przez pierwszego redaktora „Przeglądu Teologicznego”, ks. Teofila Długosza (podpisanego: X. T. D.), jest pierwszą z serii licznych recenzji, omawiających polskie i zagraniczne monografie dotyczące biblistyki Nowego Testamentu, zamieszczanych na łamach „Przeglądu Teologicznego”, a następnie „Collectanea Theologica”. 
W drugim tomie czasopisma ks. Wilhelm Michalski, w dwuczęściowym artykule Pneumatyczny charakter Ewangelij (PT 2/1921, s. 16-32, 121-146), w ciekawy sposób przeciwstawia się stanowisku Klemensa Aleksandryjskiego, że Ewangelie synoptyczne poświęcone są sprawom cielesnym, a Ewangelia Janowa jest Ewangelią duchową. Argumentuje, że wszystkie Ewangelie są duchowe, a Ewangelia Jana różni się od synoptycznych tylko stopniem (tamże, s. 17). Z drugiej strony zajmuje stanowisko w szeroko do dziś dyskutowanej kwestii gatunku literackiego Ewangelii Markowej, argumentując, że Markowe opowiadanie nie ma cech biografii starożytnych, gdyż brakuje w nim chronologii wydarzeń, opisu stosunków rodzinnych oraz relacji na temat wcześniejszego życia i działalności Jezusa, za to jest ono tak ułożone, by prowadziło do wiary w Jego osobę i posłannictwo (tamże, s. 27). To samo dotyczy też pozostałych trzech Ewangelii. Dlatego modne w ówczesnej biblistyce historyczno-krytycznej separowanie Ewangelii Janowej od synoptyków warszawski biblista ocenia bardzo negatywnie, twierdząc, że bazuje ono na niezrozumieniu wczesnochrześcijańskiego pojęcia „ewangelia” jako przede wszystkim wzbudzania i umacniania wiary w Jezusa Chrystusa, a nie zapisywania historii (tamże, s. 144-145). W kwestii pochodzenia i zależności literackich między Ewangeliami ks. Michalski z jednej strony deklaruje, że nie chce utrzymywać ,za krytyką”, iżby Ewangelia św. Marka była pierwszą Ewangelią i źródłem dla trzech innych (tamże, s. 24), ale z drugiej strony argumentuje, że Mateusz w układzie swego opowiadania szedł za wzorem Markowym (tamże, s. 29).

W artykule Źródła księgi Dziejów Apostolskich (PT 3/1922, s. 113-123) ks. Władysław Szczepański omawia teorię źródeł A. Harnacka, a następnie argumentuje, że Łukasz mógł korzystać w swej pracy z autopsji oraz ze źródeł ustnych i pisanych, zwłaszcza w komponowaniu mów (tamże, s. 117-118). W polemice do niektórych teorii krytycznych warszawski biblista twierdzi ponadto, że Łukasz nie korzystał z listów Pawłowych (choć List do Filemona i List do Kolosan znał z autopsji) ani też z dzieł Józefa Flawiusza, gdyż zbyt małe są zbieżności leksykalne między nimi (tamże, s. 119-123). 
Ksiądz Aleksy Klawek, późniejszy redaktor naczelny czasopisma, w artykule Współczesne badanie historyczne Nowego Testamentu (PT 3/1922, s. 124-136) sytuuje ówczesną biblistykę katolicką w nurcie apologetycznym, w opozycji do krytyki liberalnej. Za encykliką Leona XIII Providentissimus Deus lwowski biblista podkreśla znaczenie egzegezy ukierunkowanej historyczno-filologicznie (tamże, s. 125, 136). W artykule Gloria in excelsis Deo (PT 5/1924, s. 217-235) broni nawet historyczności słów aniołów z Łk 2,14, zaznaczając co prawda, że nie chodzi o zapis ich ipsissima verba (tamże, s. 221). Historyczności Ewangelii w opozycji do zarzutów jednego z liberalnych filologów polskich broni także lwowski biblista ks. Szczepan Szydelski w artykule Filolog o ewangelji Bożego Narodzenia (PT 4/1923, s. 112-139).

W kolejnych tomach czasopisma zainteresowanie badaniami nad Nowym Testamentem nieco spada. Artykuły nowotestamentalne pojawiają się rzadziej. Ich autorami zaczynają być natomiast nie tylko profesorowie uniwersyteccy, ale także bibliści związani ze szkołami gimnazjalnymi.

Ksiądz Władysław Hozakowski w trzyczęściowym artykule Marja Magdalena w ewangeliach (PT 6/1925, s. 1-28, 144-156, 283-318) analizuje ewangeliczne wzmianki o grzesznicy galilejskiej (Łk 7,36-50), Marii Magdalenie i Marii z Betanii. Poznański biblista argumentuje, że grzesznica galilejska, Maria z Betanii i Maria Magdalena to jedna i ta sama osoba (tamże, s. 4, 28, 312), zaś namaszczenie w Betanii jest powtórzeniem namaszczenia galilejskiego przez tę samą osobę (tamże, s. 17).

Ksiądz Stefan Siwiec, dyrektor gimnazjum z Rybnika, w artykule Nowy sposób wyjaśnienia tekstu I Kor. 7, 36-38 (PT 7/1926, s. 225-239) proponuje interpretację tego tekstu jako odnoszącego się do pana i niewolnicy, a nie ojca i córki lub narzeczonego i narzeczonej (tamże, s. 233).

Ksiądz Antoni Gagatnicki, prefekt szkolny z Przeworska, w dwuczęściowym artykule Zesłanie Ducha Świętego w świetle krytyki historycznej (PT 8/1927, s. 162-180, 307-314) uzasadnia historyczność Łukaszowego opisu tego wydarzenia z początków Kościoła, 
sprzeciwiając się przy tym utożsamianiu Łukaszowego mówienia obcymi językami z Pawłową glossolalią (tamże, s. 177-178, 313-314).

Ksiądz Piotr Stach w także dwuczęściowym artykule zatytułowanym Miejsce powstania listów więziennych św. Pawła (PT 10/1929, s. 98-117, 220-258) analizuje funkcjonujące do dzisiaj trzy główne hipotezy w tej kwestii: więzienia rzymskiego, cezarejskiego i efeskiego, poświęcając najwięcej uwagi hipotezie trzeciej, najmłodszej. Lwowski biblista, doceniając argumenty przemawiające za tą propozycją, opowiada się jednak ostatecznie za hipotezą rzymską, uzasadniając swe stanowisko przekonaniem o historycznej wiarygodności Dziejów Apostolskich oraz najstarszej tradycji chrześcijańskiej (tamże, s. 257).

W pierwszym tomie czasopisma o nowej nazwie „Collectanea Theologica” (dalej: CT), z poszerzonym o odbiorców zagranicznych zakresem zamierzonego oddziaływania publikowanych tekstów, pojawia się po raz pierwszy nowotestamentalny artykuł nie w języku polskim. Jest nim łaciński tekst I.-M. Vosté Concilium Hierosolymitanum (CT 12/1931, s. 153-189). Po analizie tekstu Dz 15,1-35 dominikanin z rzymskiego Collegium Angelicum uzasadnia historyczność dekretu apostolskiego (tamże, s. 180-184). Analizując dyskutowany do dzisiaj problem relacji między Łukaszowym opowiadaniem w Dz 15 a Pawłową relacją w Ga 2,1-10, stwierdza, że oba teksty opisują to samo wydarzenie, aczkolwiek z argumentacyjnie odmiennych punktów widzenia (tamże, s. 189).

Po kilkuletniej nieobecności artykułów nowotestamentalnych w czasopiśmie pojawia się artykuł ks. Eugeniusza Dąbrowskiego Rodzaj literacki Ewangelij synoptycznych (CT 16/1935, s. 531-566). Warszawski biblista dokonuje w nim dobrego przeglądu ówczesnych badań na temat tej do dziś szeroko dyskutowanej kwestii i stwierdza, że Ewangelie mają pewne cechy klasycznych biografii starożytnych, ale też wyraźnie się od nich różnią (tamże, s. 545). Według niego Ewangelie jako całość należą raczej do literatury semickiej niż greckiej (tamże, s. 548), przy czym ich „typy literackie” są różne u poszczególnych synoptyków (tamże, s. 564). Dąbrowski wykorzystuje w swej analizie elementy popularnej wówczas metody krytyki form (Formgeschichte), sugerując istnienie krótkich, katechetycznych, 
przed-ewangelicznych formuł aforystycznych, dotyczących także wydarzeń z życia Chrystusa (tamże, s. 564), a także odrębnych, być może nawet pisanych, ,schematów ewangelizacji”, dostosowanych do trzech głównych typów gmin chrześcijańskich: Żydów w Palestynie, Żydów w diasporze i pogan (tamże, s. 555).

Mimo stosunkowo niewielkiej liczby artykułów nowotestamentalnych publikowanych wówczas w czasopiśmie, w dziale „Theologia nostri aevi” pojawia się omówienie aktualnego stanu badań nad Nowym Testamentem w literaturze światowej pióra ks. Eugeniusza Dąbrowskiego (CT 17/1936, s. 530-550), a także, w dziale „Notanda”, relacja z pierwszego zjazdu biblistów polskich w Krakowie pióra ks. Piotra Stacha (CT 18/1937, s. 701-711).

W naznaczonym wojną roku 1939 ukazuje się jeszcze dwuczęściowy artykuł biblijny Emila Kuli z Bogumina Nowego, na zaanektowanym przez Polskę w 1938 r. Zaolziu, pod tytułem Das Reich Gottes im Alten und Neuen Testament (CT 20/1939, s. 83-109, 191-198). Czeski biblista twierdzi w swym tekście, wbrew rozpowszechnionym wówczas w literaturze poglądom, że Jezusowa koncepcja królestwa Bożego nie była koncepcją apokaliptyczną (tamże, s. 198).

W pierwszym, przedwojennym, okresie istnienia czasopisma, profesorowie uniwersyteccy piszący artykuły dotyczące Nowego Testamentu mieli więc dobre przygotowanie do badań filologicznych, literackich, egzegetycznych i teologicznych. Byli przy tym świadomi oryginalności egzegezy wiernej Magisterium Kościoła katolickiego, zwłaszcza ówcześnie miarodajnej encyklice Leona XIII Providentissimus Deus, na tle egzegezy liberalnej, uprawianej w krajach zachodniej Europy, ale także niekiedy w Polsce.

\section{Trudny okres powojenny (1949-1965)}

Po przerwie spowodowanej II wojną światową i jej tragicznymi następstwami, wznowienie wydawania „Collectanea Theologica” nastąpiło w 1949 r. Tak zwany naukowy ateizm był już wówczas bardzo wyraźnie obecny w państwowej propagandzie, ale z początku 
nie wpływał w istotny sposób na treść publikowanych w czasopiśmie artykułów.

W pierwszym powojennym zeszycie czasopisma ukazały się aż dwa artykuły nowotestamentalne. W pierwszym z nich, zatytułowanym Le problème de la descente du Christ aux enfers dans la 1 épître de S. Pierre (CT 21/1949, s. 42-76), warszawski biblista, ks. Seweryn Kowalski, podjął się egzegezy tekstu 1P 3,18b-4,6 na tle interpretacji tradycyjnych i współczesnych. Stanął na stanowisku, że zstąpienie Chrystusa do piekieł nie anulowało istnienia piekła, lecz było dobra nowiną dla dusz nawróconych do Boga (tamże, s. 76).

$\mathrm{Z}$ kolei ks. Bogdan (później: Augustyn OSB) Jankowski w dwuczęściowym artykule Schola Historiae Formarum quid de resuscitationibus evangelicis sentiat? (CT 21/1949, s. 77-106, 219-258) przeprowadził analizę poglądów M. Dibeliusa i R. Bultmanna na kwestię ewangelicznych opisów cudów, zwłaszcza cudów wskrzeszenia umarłych. Warszawski biblista krytycznie opisał przy tym założenia i metodę szeroko rozpowszechnionej wówczas w biblistyce szkoły badań historii form (Formgeschichte), zarzucając jej wyolbrzymianie podobieństw ewangelicznych opisów z literaturą pozabiblijną, zbytni racjonalizm w podejściu do cudów oraz przeakcentowanie roli środowiska społecznego, tzw. Sitz im Leben (tamże, s. 236).

Ksiądz Seweryn Kowalski w artykule „Petra enim erat Christus” (1. Cor 10, 5) (CT 21/1949, s. 199-218) przeanalizował Pawłowy tekst 1Kor 10,3-4 na tle historii działalności misyjnej Apostoła Narodów. Doszedł przy tym do wniosku, że Paweł nie odwoływał się w omawianym tekście do określonych fragmentów Starego Testamentu, ale do Chrystusa pneumatycznego, przed Jego wcieleniem (tamże, s. 217).

Po tych obiecujących początkach nastąpiła w „Collectanea Theologica" kilkuletnia przerwa w publikowaniu artykułów nowotestamentalnych. Ciszę tę przerwał w 1955 r. artykuł ks. Wincentego Kwiatkowskiego, zatytułowany $Z$ nowszych badan nad ,prehistoria”, opisu ewangelijnego o zmartwychwstaniu Chrystusa (CT 26/1955, s. 311-352). Jest to w istocie artykuł recenzyjny, w którym warszawski apologeta poddał krytyce tezę szkoły historii form (Formgeschichte) o wytworzeniu tradycji ewangelicznej przez najstarszą gminę (tamże, 
s. 319). Opowiedział się natomiast za pochodzeniem najstarszej tradycji ,urzędowej”, dotyczącej zmartwychwstania Chrystusa, od grupy Dwunastu (tamże, s. 351).

$\mathrm{Z}$ kolei artykuł ks. Michała Petera Powtórne przyjście Eliasza w świetle Starego i Nowego Testamentu (CT 27/1956, s. 5-33) w swej części nowotestamentalnej dowodzi na podstawie egzegezy odnośnych tekstów ewangelicznych, że Chrystus nie spodziewał się powtórnego przyjścia Jana Chrzciciela przy końcu świata (tamże, s. 24-25).

W krótkim artykule „Manna absconditum” (Ap 2, 17) quonam sensu ad Eucharistiam referatur (CT 29/1958, s. 3-9) o. Augustyn Jankowski OSB broni ciekawej tezy o obecności hermeneutycznej typologii nie tylko w Starym, ale także Nowym Testamencie. Tyniecki biblista twierdzi bowiem, zgodnie z klasyczną teorią różnych sensów tekstu biblijnego (w tym przypadku: dosłownego, alegorycznego i anagogicznego), że wyrażenie „manna ukryta” w Ap 2,17 odnosi się nie tylko do manny historycznej i do Eucharystii, ale także do wiecznego rozkoszowania się boskością (tamże, s. 9).

Po latach skąpej obecności artykułów nowotestamentalnych w i tak ogólnie skromnie wydawanym w latach powojennych czasopiśmie bardzo dużą wartość ma napisany przez o. Augustyna Jankowskiego OSB obszerny artykuł Znak spod Nain (CT 33/1962, s. 5-180). Znakiem czasu, związanym prawdopodobnie nie tyle z rozpoczynającym się w 1962 r. II Soborem Watykańskim, ile z potrzebą dotarcia do jak najszerszego grona ogólnie wykształconych czytelników polskich, było opublikowanie artykułu przez benedyktyńskiego mnicha po polsku, a nie - jak dotąd - po łacinie. Tyniecki biblista rzetelnie przeanalizował w nim perykopę Łk 7,11-17 pod kątem historii jej interpretacji w tradycji chrześcijańskiej (tamże, s. 8-19), a następnie zajął się poglądami nowożytnej krytyki racjonalistycznej na cuda wskrzeszeń (tamże, s. 20-31). Następnie, w zasadniczej części rozprawy, z metodologiczną rzetelnością przeanalizował wszystkie trzy ewangeliczne opisy wskrzeszeń (córki Jaira, młodzieńca z Nain i Łazarza) z punktu widzenia krytyki tekstu, krytyki literackiej, krytyki historycznej, krytyki źródeł oraz analizy apologetyczno-teologicznej (tamże, s. 42-178). Taka rzetelna analiza naukowa ewangelicznych 
opisów cudów wskrzeszeń, zwłaszcza wskrzeszenia młodzieńca z Nain, była niezwykle istotna w kontekście szerzonej wówczas przez państwo propagandy i nauki ateistycznej.

Kolejną ważną publikacją nowotestamentalną z owego okresu jest obszerny artykuł ks. Jana Stępnia Autentyczność listów do Tesaloniczan (CT 34/1963, s. 91-182). Warszawski biblista przeanalizował $\mathrm{w}$ nim tytułowe zagadnienie $\mathrm{z}$ punktu widzenia dokumentacji patrystycznej oraz cech językowych, literackich i teologicznych tych listów (tamże, s. 95-136). Następnie zajął się analizą argumentów przeciw autentyczności listów do Tesaloniczan, by stwierdzić, że oba listy są autentycznie Pawłowe (tamże, s. 177-180). Na tle skromnej wówczas polskiej literatury teologicznej studium ks. Stępnia przedstawia dużą wartość.

Krótki artykuł ks. Kazimierza Romaniuka „,Ja jestem, nie bójcie się!” Przyczynek do nowotestamentalnej teologii bojaźni Boga (CT 35/1964, s. 63-72) poświęcony jest analizie literackiej i apologetycznej tytułowej formuły. W tekście warszawskiego biblisty po raz kolejny ujawnia się silny związek polskiej powojennej egzegezy Nowego Testamentu z apologetyką.

Ów silny związek powojennych badań nad Nowym Testamentem z apologetyką był po części spowodowany kontekstem propagowanego przez państwo materializmu ateistycznego, z którym musieli się zmierzyć polscy teologowie. Wydaje się jednak, że równie istotnym czynnikiem była pozycja apologety ks. Wincentego Kwiatkowskiego w warszawskim środowisku teologicznym, zwłaszcza związanym z czasopismem „Collectanea Theologica”, którego był redaktorem naczelnym w latach 1949-1964, a także z Akademią Teologii Katolickiej, w której pełnił funkcję dziekana Wydziału Teologicznego (1954-1956), a następnie rektora (1956-1965).

\section{Skromny okres posoborowy (1966-1974)}

Po rocznej przerwie w wydawaniu „Collectanea Theologica” w 1965 r., opublikowany na kanwie zakończonego niedawno II Soboru Watykańskiego artykuł ks. Henryka Bogackiego SJ Konstytucja 
II Soboru Watykańskiego o Bożym Objawieniu „Dei Verbum” (CT 36/1966, s. 74-92) jest z konieczności, ze względu na bardzo małą jeszcze wówczas objętość całego czasopisma, skrótowym omówieniem treści tego ważnego dokumentu Magisterium Kościoła. W jego części nowotestamentalnej warszawski dogmatyk zwrócił uwagę na unikanie w tekście soborowym w odniesieniu do historyczności Ewangelii podejścia fundamentalistycznego oraz wręcz prowokowanie do posługiwania się metodą historii rozwoju form literackich (tamże, s. 87).

Zgodnie z zamieszczoną w nocie redakcyjnej w numerze 37(1967) fasc. 1, s. 5 deklaracją, artykuły publikowane w „Collectanea Theologica" miały mieć odtąd, po II Soborze Watykańskim, charakter teologiczno-duszpasterski i być zrozumiałe także dla niespecjalistów. Pomijając pytanie, czy takie były rzeczywiście intencje Soboru, należy stwierdzić, że o ile do tego okresu nowotestamentalne publikacje w czasopiśmie były dość często fragmentami obszerniejszych rozpraw naukowych, o tyle odtąd publikowane w „Collectanea Theologica" artykuły dotyczące Nowego Testamentu stały się mniej fachowe, przynajmniej od strony stosowanego w nich języka.

Krótki artykuł ks. Feliksa Gryglewicza Dwie wzmianki o chrzcie w Ewangelii św. Jana (CT 37[1967] fasc. 1, s. 66-76) wpisuje się w popularny do dzisiaj nurt badań nad sakramentologią czwartej Ewangelii. Lubelski biblista ukazuje w nim, że sakramentologia ta ma charakter zróżnicowany: o ile w J 3,1-21 wzmianki o chrzcie są według niego bardziej wyraźne, to w J 9,1-41 mają charakter jedynie aluzyjny (tamże, s. 75).

Również krótki artykuł ks. Janusza Czerskiego Chrystocentryzm Kościoła w Ewangelii św. Mateusza (CT 37[1967] fasc. 3, s. 35-48) wpisuje się z kolei w posoborowy nurt teologii chrystocentrycznej. Przeprowadzona przez nyskiego biblistę analiza Mateuszowych opisów cudów Jezusa nie ma więc, jak w analogicznych artykułach publikowanych wcześniej w czasopiśmie, charakteru apologetycznego, ale podkreśla władzę i moc Chrystusa jako Pana (tamże, s. 42).

Nieco podobny charakter ma artykuł ks. Józefa Wilka Triumf Baranka jako idea przewodnia Apokalipsy (CT 40[1970] fasc. 3, 
s. 45-61). Lubelski biblista skupia się w nim nie tyle na różnych sposobach interpretacji proroctw tej księgi, ile na ukazaniu jej chrystocentrycznego charakteru, polegającego na uczynieniu figury Baranka centralną figurą Apokalipsy (tamże, s. 60).

Siostra Teresa Czekała FMA jest natomiast pierwszą kobietą i pierwszą siostrą zakonną, która opublikowała na łamach „Collectanea Theologica” artykuł dotyczący Nowego Testamentu. Jej krótki tekst $Ł k$ 1, 34 w egzegezie katolickiej XX wieku (CT 41[1971] fasc. 3, s. 29-40) stanowi przegląd egzegetycznych interpretacji słów Maryi: „Jakże się to stanie, skoro męża nie znam?” Michalicka biblistka opowiada się przy tym za hipotezą, że słowa te nie oznaczają przede wszystkim jakiegoś wewnętrznego pragnienia trwania w dziewictwie, ale raczej odzwierciedlają niemożność spełnienia się zapowiedzi anioła (tamże, s. 40).

Nieco obszerniejszy artykuł ks. Jana Stępnia Kościół Ciałem Chrystusa $w$ wielkich listach św. Pawła (CT 41[1971] fasc. 4, s. 25-44) dotyczy istotnego dla teologii posoborowej tematu eklezjologii opartej na nowotestamentalnej metaforze Ciała Chrystusa. Analizując ten temat, warszawski biblista podkreślił następujące cechy Kościoła: jedność, świętość i służebną hierarchiczność (tamże, s. 43).

Artykuł Zbigniewa Żabińskiego Trzydzieści srebrników (CT 43[1973] fasc. 2, s. 65-75) ma charakter historyczno-apologetyczny. Krakowski autor analizuje w nim wartość nabywczą monet w Palestynie czasów Chrystusa i stwierdza na tej podstawie, że odniesienia do niej mają w Ewangeliach charakter spójny nie tylko wewnętrznie ale i z innymi źródłami, co według autora musi wskazywać na palestyńskie pochodzenie tradycji ewangelicznej (tamże, s. 74-75).

$\mathrm{Z}$ kolei krótki artykuł ks. Mirosława Kokota SDB Znaczenie nasienia $w$ Łukaszowej przypowieści o siewcy (CT 43[1973] fasc. 2, s. 77-83) stanowi próbę zastosowania nowej w Polsce na owe czasy metody badań historii redakcji (Redaktionsgeschichte). Jednak mimo deklarowanego przez krakowskiego salezjanina zainteresowania Łukaszową redakcją (tamże, s. 83), wypunktował on w istocie jedynie specyficzne cechy Łukaszowej wersji przypowieści, bez stosowania innych elementów tej naukowej metody. 
Natomiast artykuł ks. Kazimierza Romaniuka Przeciwnicy Pawła w Galacji (CT 43[1973] fasc. 4, s. 29-35), choć również bardzo skromny objętościowo, podejmuje zagadnienie bardzo istotne egzegetycznie, do dzisiaj szeroko dyskutowane w biblistyce Nowego Testamentu. Warszawski naukowiec przedstawił syntetycznie ówczesne poglądy w tej kwestii, a następnie opowiedział się za hipotezą widzącą w Pawłowych oponentach w Galacji judeochrześcijan (tamże, s. 35).

Mimo panującej w teologii posoborowej odnowy biblijnej, publikacja artykułów nowotestamentalnych w „Collectanea Theologica” miała zatem w latach 1966-1974 charakter sporadyczny i skąpy objętościowo, a przy tym dość syntetyczny lub przyczynkarski w treści.

\section{Czas ograniczonego rozwoju (1975-1979)}

Sytuacja biblistyki nowotestamentalnej na łamach „Collectanea Theologica” zaczęła zmieniać się na lepsze w 1975 r. Opublikowany wówczas artykuł ks. Kazimierza Romaniuka Zagadnienie paulinizmów w Ewangelii św. Marka (CT 45[1975] fasc. 3, s. 19-29) dotyka zagadnienia bardzo kontrowersyjnego, także dzisiaj mocno dyskutowanego przez nowotestamentalistów. Warszawski biblista krytycznie ocenia w nim ówczesny stan badań w tej kwestii, a następnie opowiada się za obecnością paulinizmów jedynie w pewnych fragmentach Ewangelii Markowej, zwłaszcza w perykopie o celu przypowieści Mk 4,11-12 i logionie o bluźnierstwie przeciwko Duchowi Świętemu Mk 3,28-29 (tamże, s. 28-29).

W pierwszym obcojęzycznym numerze specjalnym „Collectanea Theologica", mającym za zadanie ukazać teologom z zagranicy aktualny stan teologii polskiej, ukazał się artykuł ks. Jana Stępnia Das Apostolat in biblischer Sicht (CT 45[1975] fasc. spec., s. 75-85). Warszawski biblista ukazał w nim znaczenie powszechnego apostolatu wierzących na tle odniesienia do hierarchii (tamże, s. 83-85). Ta współczesna dychotomia teologiczna wpłynęła jednak negatywnie na ujęcie problemu, nieadekwatnie ukazujące zwłaszcza specyfikę apostolatu Pawłowego. 
W kolejnych zeszytach „Collectanea Theologica” artykuły nowotestamentalne zaczęły się pojawiać wyraźnie częściej. Dość obszerny artykuł ks. Jana Szlagi Zbudowani na fundamencie apostołów i proroków (CT 46[1976] fasc. 1, s. 45-65) dotyczy problemów egzegetycznych tekstu Ef 2,19-22. Lubelski biblista opowiada się za hipotezą częściowego przynajmniej utożsamienia tytułowych apostołów i proroków jako wybranych przez Chrystusa najbliższych jego współpracowników (tamże, s. 54). Zwraca przy tym uwagę, zgodnie z ówczesnym kierunkiem rozwoju teologii, na chrystocentryzm omawianego tekstu (tamże, s. 64), ale nie wchodzi w bardziej fachowe problemy autorstwa Ef 2,19-22 i jego możliwej funkcji jako tekstu po-Pawłowego.

Znakiem coraz wyraźniejszego zainteresowania autorów i redakcji tematyką nowotestamentalną jest fakt, że w zeszycie CT 46(1976) fasc. 3 po raz pierwszy w historii czasopisma pojawiły się jednocześnie aż trzy artykuły z biblistyki Nowego Testamentu. Pierwszy z nich, autorstwa ks. Henryka Muszyńskiego, nosi tytuł Kuszenie Chrystusa $w$ tradycji synoptycznej (CT 46[1976] fasc. 3, s. 17-41). Synoptyczne opisy kuszenia Chrystusa warszawski biblista poddaje analizie z punktu widzenia krytyki literackiej, problemu synoptycznego, rodzaju literackiego, treści teologicznej, a także - co nie zawsze miało miejsce w ówczesnej biblistyce międzynarodowej - krytyki historycznej, broniąc historyczności kuszenia Chrystusa (tamże, s. 40).

Krótki artykuł o. Hugolina Langkammera OFM Credo pierwotnych Kościołów (CT 46[1976] fasc. 3, s. 43-49) przedstawia próbę zastosowania metody historii form (Formgeschichte) do tekstów Pawłowych, ukazując zawarte w nich formuły wiary i aklamacje. Lubelski biblista wskazuje następnie na obecność aklamacji chrystologicznych także w Ewangelii Janowej. Na podstawie tego kryterium formalnego argumentuje nieco ryzykownie, że czwarta Ewangelia opiera się na starych tradycjach (tamże, s. 49).

Również krótki artykuł ks. Eugeniusza Szewca ,Chwały” w listach Judy i 2 Piotra (CT 46[1976] fasc. 3, s. 51-60) przedstawia różne możliwości interpretacji tytułowego określenia „Chwały”. Łódzki biblista opowiada się przy tym za jego interpretacją jako 
odnoszącego się do upadłych aniołów (tamże, s. 57). Co ciekawe, bodajże po raz pierwszy w artykułach nowotestamentalnych publikowanych na łamach „Collectanea Theologica” pojawia się w nim analiza tła qumrańskiego (tamże, s. 57-59). Dowodzi to stopniowego otwierania się polskiej biblistyki nie tylko - jak dotąd - na kwestie związane z Formgeschichte i klasyczną egzegezą tekstu, ale także na nowsze problemy badawcze.

Artykuł ks. Janusza Czerskiego Męka Pańska w Ewangeliach synoptycznych $w$ świetle krytyki historyczno-literackiej (CT 46[1976] fasc. 4, s. 29-43) stanowi natomiast przykład bardziej tradycyjnego podejścia do badania tekstu opartego na analizie źródła literackiego (Urbericht) i historii formy (Formgeschichte). Jak na owe czasy tekst opolskiego biblisty był wartościową analizą problemu, odpowiadającą standardom biblistyki międzynarodowej, o czym świadczy także jego opublikowanie w języku niemieckim w CT 46(1976) fasc. spec., s. 81-96.

W obcojęzycznym zeszycie specjalnym CT 46(1976) fasc. spec. na trzynaście opublikowanych artykułów aż cztery dotyczyły biblistyki Nowego Testamentu. Jednym z nich był wspomniany wyżej artykuł ks. Janusza Czerskiego. Poza tym, ks. Edward Szymanek TChr opublikował tekst Glaube und Unglaube im Evangelium des hl. Johannes (CT 46[1976] fasc. spec., s. 97-121). Poznański biblista przeanalizował w nim tytułowe zagadnienie wiary i niewiary w kategoriach lingwistyczno-teologicznych. Szkoda, że w artykule brakuje syntetycznego omówienia wyników całej analizy.

Króciutki tekst ks. Kazimierza Romaniuka Le problème de l'activité missionnaire de Saint Pierre à Corinthe (CT 46[1976] fasc. spec., s. 123-125) jest właściwie recenzją pewnego niedawno opublikowanego artykułu, odnoszącego się do tej kwestii. Warszawski biblista ocenia go negatywnie, argumentując, że do hipotezy pobytu Piotra w Koryncie trzeba podchodzić z dużą rezerwą (tamże, s. 125).

$\mathrm{Na}$ tle tekstów publikowanych we współczesnych językach zachodnich artykuł ks. Józefa Kudasiewicza Circumstans peccatum (Hbr 12, 1) (CT 46[1976] fasc. spec., s. 127-140) stanowi łacińskojęzyczny wyjątek. Kielecki biblista poświęcił go krytyce tekstu 
Hbr 12,1, uzasadniając pierwotność lekcji z rzeczownikiem hamartia (tamie, s. 140).

Trudnego i szeroko do dzisiaj dyskutowanego problemu stanowiska Kościoła katolickiego względem rozwodów dotyka artykuł ks. Jana Załęskiego Elementy egzegezy patrystycznej we współczesnych interpretacjach tekstu Mt 5,32 czy 19,9 (CT 47[1977] fasc. 1, s. 43-63). Warszawski biblista analizuje w nim tzw. Mateuszową ,klauzulę rozwodową", argumentując, że liberalne (w przypadku Ambrozjastra) lub niezdecydowane stanowisko niektórych Ojców Kościoła w tej kwestii należy wyjaśniać w kontekście całości ich wypowiedzi jako obronę nierozerwalności małżeństwa, z ewentualnym zezwoleniem na separację lub stwierdzenie nieważności małżeństwa (tamże, s. 61-62). Ksiądz Załęski argumentuje także, że „klauzula rozwodowa” w Mt 5,32 balansowana jest w dalszej części zdania brakiem zgody na wzięcie oddalonej kobiety za żonę (tamże, s. 62-63). Nie analizuje jednak problemu, czy ta dalsza część zdania dotyczy każdej kobiety, czy tylko takiej, której nie dotyczy wprowadzona w pierwszej części zdania ,klauzula rozwodowa”, ani też nie analizuje w tym kontekście kwestii zawarcia powtórnego małżeństwa przez pierwszego męża.

Świadectwem otwierania się polskiej biblistyki Nowego Testamentu na aktualne problemy eklezjalne jest także artykuł ks. Stefana Moysy SJ Z problematyki charyzmatów Ducha Świętego (CT 47[1977] fasc. 3, s. 17-38). W kontekście rozwijającego się także w Polsce ruchu charyzmatycznego warszawski jezuita analizuje Pawłowe określenia charyzmatów, kwestię ich źródeł i pochodzenia oraz relację pomiędzy charyzmatem z instytucją. Apeluje, by charyzmaty w Kościele rozróżniać, ale nie „gasić Ducha” (tamże, s. 37).

Artykuł ks. Kazimierza Romaniuka La justice de Dieu dans l'Epître de Saint Paul aux Romains, opublikowany w zeszycie obcojęzycznym (CT 47[1977] fasc. spec., s. 139-148), dotyka jednej z najtrudniejszych kwestii teologicznych, jaką jest kwestia Pawłowej nauki o sprawiedliwości Bożej i usprawiedliwieniu. Warszawski biblista argumentuje, że według Pawła sprawiedliwość Boża jest synonimiczna z miłością Boga i umożliwia człowiekowi uczestnictwo we właściwościach samego Boga (tamże, s. 148). Artykuł ks. Romaniuka 
został też opublikowany w języku polskim w CT 48(1978) fasc. 1, s. $71-81$.

Artykuł ks. Andrzeja Suskiego $W$ kwestii integralności opisu zwiastowania (Łk 1, 26-38) (CT 48[1978] fasc. 3, s. 31-42) analizuje tytułowe zagadnienie, opierając się na literackiej analizie tekstu i wykryciu w jego całości struktury koncentrycznej. Na tej podstawie warszawski biblista wypowiada się przeciwko uznawaniu Łk 1,34 oraz Łk 1,35-38 za interpolacje (tamże, s. 40-41). Wykrywanie w tekstach biblijnych struktur koncentrycznych było wówczas, w okresie mody na strukturalizm w nauce, często stosowane w biblistyce, więc artykuł ks. Suskiego dobrze wpisuje się w nurt międzynarodowych badań nad Nowym Testamentem.

Istotnym przyczynkiem do posoborowego opracowania teologii moralnej Nowego Testamentu jest artykuł ks. Kazimierza Romaniuka Pokuta i pojednanie w Nowym Testamencie (CT 48[1978] fasc. 4, s. 15-34). Warszawski biblista nie unika w nim trudnych pytań o cel i zakres istnienia kar w Kościele (tamże, s. 30-32), co nie było tematem często poruszanym w posoborowej teologii moralnej na Zachodzie. Prawdopodobnie także z tego względu artykuł został opublikowany także w języku francuskim w CT 48(1978) fasc. spec., s. $83-101$.

Nieco podobnej problematyki moralnej dotyka artykuł ks. Jana Stępnia Syneidesis (das Gewissen) in der Anthropologie des Apostels Paulus (CT 48[1978] fasc. spec., s. 61-81). Po przedstawieniu starożytnego tła użycia tytułowego określenia, warszawski biblista opisuje jego użycie w Nowym Testamencie. Nie dochodzi jednak, niestety, do bardziej syntetycznych konkluzji na temat nowotestamentalnej teologii sumienia.

Pogranicza teologii moralnej i teodycei dotyka również artykuł ks. Henryka Muszyńskiego Bóg a zło w Piśmie Świętym (CT 49[1979] fasc. 2, s. 23-47). W jego nowotestamentalnych partiach warszawski biblista stwierdza, że Chrystus, zmartwychwstając, zwyciężył wszelkie formy zła w świecie (tamże, s. 46). Szkoda, że analizując eschatyczną wizję Apokalipsy, podkreśla jedynie jej triumfalistyczny aspekt zwycięstwa (tamże), nie pisząc o rzeczywistości pozostającej 
stale „na zewnątrz” (Ap 22,15), co miałby znaczenie dla toczonych z nowym impetem w teologii posoborowej sporów o istnienie i charakter piekła.

Druga połowa lat siedemdziesiątych XX w. była więc czasem odważniejszego wchodzenia w problemy egzegetyczne i teologiczno-biblijne. Ważną cechą tego okresu było także odważne wyjście w świat przez publikacje artykułów w językach obcych.

\section{Papieskie impulsy w rzeczywistości ograniczonego rozwoju (1980-1990)}

Po wyborze kard. Karola Wojtyły na Stolicę Piotrową wszystkie artykuły zeszytu CT 50(1980) fasc. 2 z pewnym opóźnieniem poświęcone były teologii Karola Wojtyły i papiestwu. Natomiast w kolejnych zeszytach powracają artykuły z różnych dziedzin teologii, w tym biblistyki Nowego Testamentu.

W coraz intensywniej toczącą się dyskusję nad problemem synoptycznym włącza się bp Kazimierz Romaniuk w artykule Refleksje na temat pewnej krytyki źródła Q (CT 52[1982] fasc. 4, s. 31-46). Warszawski biblista zawiera w nim swą negatywną ocenę dość oryginalnego podejścia do problemu synoptycznego, propagowanego przez Michaela Gouldera, nie negując jednak postulowanej przez niego możliwości pewnej zależności Ewangelii Łukasza od Ewangelii Mateusza (tamże, s. 46). Artykuł bp. Romaniuka pośrednio świadczy o roli, jaką dla niektórych polskich biblistów miała możliwość wyjeżdżania na międzynarodowe konferencje biblistyczne na Zachodzie i poznawania tam nowych podejść do różnych problemów naukowych.

Ten sam autor w artykule „Ani sandatów, ani laski” (Mk 6, 8-9; Mt 10, 9-10; Łk 9, 3) (CT 57[1987] fasc. 1, s. 5-14) omawia problem tytułowego zakazu Jezusa w ujęciu trzech synoptyków. Broni przy tym synoptycznej hipotezy istnienia źródła Q i, stosując metodę badania historii tradycji (Traditionsgeschichte), rekonstruuje sposób wykorzystania materiału z tego źródła przez trzech synoptyków, włączając Marka (tamże, s. 12). Takie ujęcie problemu jest dość odważne, 
gdyż sytuuje warszawskiego biblistę nieco z boku głównego nurtu ówczesnych badań nad źródłem Q, według których Marek ze źródła $\mathrm{Q}$ raczej nie korzystał, a tzw. minor agreements między Mateuszem i Łukaszem przeciw Markowi (jak tytułowy zakaz brania na drogę laski) trzeba wyjaśniać w inny sposób.

Artykuł ks. Romana Bartnickiego Powstanie Ewangelii synoptycznych wedtug hipotezy dwóch Ewangelii w ujęciu Bernarda Orcharda (CT 59[1989] fasc. 3, s. 5-25) zawiera natomiast omówienie hipotezy naukowej, która bardzo odbiega od hipotezy dwóch źródeł (Mk i Q), przyjmowanej dość powszechnie w badaniach nad problemem synoptycznym we współczesnej biblistyce światowej i polskiej, o czym świadczą choćby publikowane w „Collectanea Theologica” artykuły bp. Romaniuka. Docenić więc należy naukową odwagę ks. Bartnickiego, który rzetelnie przeanalizował hipotezę dwóch Ewangelii (Two-Gospel Hypothesis), podkreślił jej odwołania do świadectw patrystycznych i zaapelował, by uwzględniać ją przy omawianiu problemu synoptycznego (tamże, s. 24-25).

$\mathrm{Z}$ kolei w artykule Ewangeliczne zapowiedzi męki, śmierci i zmartwychwstania $w$ świetle kryteriów autentyczności logiów Jezusa (CT 51[1981] fasc. 2, s. 53-64) ten sam autor dotyka szeroko do dzisiaj dyskutowanego zagadnienia kryteriologii w badaniach nad Jezusem historycznym, stając na dość oryginalnym w biblistyce współczesnej stanowisku, że przy stosowaniu kryteriów ciężar dowodu spoczywa na zwolennikach nieautentyczności pewnych elementów Ewangelii, a nie na zwolennikach ich autentyczności (tamże, s. 55-57).

W obszarze bardziej szczegółowych badań egzegetycznych nad dziełami synoptyków ks. Kazimierz Romaniuk w artykule ,, Józef, mąż sprawiedliwy...” (Mt 1,19) (CT 50[1980] fasc. 3, s. 25-34) optuje za interpretacją ustępczą ewangelicznego zdania podrzędnego („mimo że był sprawiedliwy”). Warszawski biblista sugeruje także, by czasownik apolyein w Mt 1,19 rozumieć w kategoriach „opuszczenia” Maryi (tamże, s. 33). Artykuł został opublikowany także w nieco poprawionej wersji francuskojęzycznej w CT 50(1980) fasc. spec., s. 123-131, uwyraźniającej oryginalną hipotezę dwóch zdań 
ustępczych w Mt 1,19 („,mimo że był mężem sprawiedliwym i mimo że nie chciał narazić jej na zniesławienie"; tamże, s. 128).

W artykule Zmiany interpunkcyjne jako jeden ze sposobów rozwiązywania niektórych problemów egzegetycznych (CT 52[1982] fasc. 1, s. 47-60) ten sam egzegeta omawia tytułową propozycję na przykładzie tekstów Mk 4,12 („Czy [tylko] wam dana jest tajemnica...?'); 1Kor 6,18 („Czy [w ogóle] jakikolwiek grzech popełniony przez człowieka pozostanie poza ciałem?”) i Ga 3,20 („Czyż nie ma pośrednika gdy chodzi o Jednego?"). Podejście warszawskiego biblisty zwraca uwagę na często pomijany w egzegezie fakt, że interpunkcja jest w tekstach biblijnym wynalazkiem dość późnym, a jej interpretacyjny charakter powinien być przedmiotem dyskusji tak samo, jak inne aspekty tekstu.

Ksiądz Jan Łach w artykule ,,Sól ziemi” (Mt 5,13) (CT 52[1982] fasc. 4, s. 47-56), opierając się na paralelizmie budowy Mt 5,13.14-16, dość tradycyjnie argumentuje, że ,ziemia” w Mt 5,13 oznacza to samo, co ,świat” w Mt 5,14 (tamże, s. 52). Warszawski biblista nie bierze więc pod uwagę możliwości zastosowania w Mt 5,13-16 paralelizmu antytetycznego, ze wszystkimi konsekwencjami tej możliwości dla interpretacji dyskutowanego tekstu Mt 5,13.

Ostatnią antytezą Kazania na Górze zajmuje się ten sam autor w artykule Die Pflicht zur Versöhnung und Liebe (Mt 5, 43-48) (CT 57[1987] fasc. spec., s. 57-69). Warszawski biblista analizuje jej strukturę literacką i treść teologiczną na tle podobnych wypowiedzi innych pism Starego i Nowego Testamentu. Argumentuje, że odniesienie do doskonałości Ojca niebieskiego (Mt 5,48) jest integralną częścią antytezy i jako takie wskazuje na przykład Ojca, wraz z przykładem chrystologicznie orientowanego zaparcia się siebie, jako wzór do wypełnienia przykazania miłości bliźniego (tamże, s. 69).

Artykuł bp. Kazimierza Romaniuka O naśladowaniu Jezusa (Mt 8, 18-22; Łk 9, 57-60) (CT 60[1990] fasc. 1, s. 5-14) poświęcony jest natomiast wyjaśnieniu trudności egzegetycznych i teologii tytułowych tekstów ewangelicznych. Warszawski biblista argumentuje przy tym, że Jezusowa odpowiedź dla uczonego w Piśmie (Mt 8,20) nie oznacza odtrącenia go, a jedynie uświadomienie mu trudności pójścia 
za Jezusem (tamże, s. 8-9). Natomiast wzmiankowani w wypowiedzi Jezusa „umarli” (Mt 8,22) to świat bez łączności z Chrystusem, podobnie jak u Pawła w Ga 2,19-20 (tamże, s. 10-11).

W artykule Die Jünger Jesu in Mt 9,35 - 11,1 (CT 58[1988] fasc. spec., s. 39-56) ks. Roman Bartnicki przedstawia wyniki swych badań nad tytułowym fragmentem, prowadzonych metodą historyczno-krytyczną. Warszawski biblista wyjaśnia problematyczny zakaz misji do pogan (Mt 10,5b-6) w kategoriach historii redakcji (Traditionsgeschichte), argumentując, że pochodzi on z palestyńskiej misji historycznego Jezusa, będącej modelem dla całej misji Kościoła, a dopiero później włączony został przez ewangelistę do redakcyjnie skomponowanej mowy skierowanej do wszystkich uczniów, dla których to ograniczenie nie jest już wiążące (tamże, s. 51-53). Zaletą takiego ujęcia jest próba dotarcia do słów historycznego Jezusa, zaś pewną wadą - metodycznie niedostateczne uwzględnienie funkcji problematycznego logionu w całej Ewangelii Mateuszowej.

W artykule Znaczenie i główna myśl przed-Markowego opowiadania o Przemienieniu Pańskim (CT 51[1981] fasc. 1, s. 33-47) ks. Mirosław Kokot SDB powraca do hipotezy istnienia literackiego pierwowzoru Ewangelii Markowej. O ile w ówczesnej biblistyce dość przyjmowano tę hipotezę dla Markowego opisu męki, salezjański biblista stosuje ją do fragmentu z głównej części Markowego dzieła. Dość odważnie rekonstruuje przy tym własną teologię tego hipotetycznego utworu (tamże, s. 46-47).

W krótkim tekście Funkcja cudów w Ewangelii Łukaszowej (CT 55[1985] fasc. 3, s. 39-44) ks. Jan Łach podkreśla, że w Łukaszowej koncepcji opisy cudów mają charakter nie tyle apologetyczny, ile soteriologiczny (tamże, s. 44). Analizy warszawskiego biblisty, podkreślające różnice między opracowaniem perykop przejętych od Marka i pochodzących z własnego materiału Łukasza, wpisują się w popularny w ówczesnej egzegezie katolickiej nurt badań metodą historii redakcji (Redaktionsgeschichte).

Ten sam autor w artykule Katechese über die Kirche von Jerusalem in der Apostelgeschichte (2,42-47; 4,32-35; 5,12-16) (CT 52[1982] fasc. spec., s. 141-153) zwraca uwagę na myślową ciągłość, charakteryzującą 
Łukaszowy zestaw summariów w pierwszej części Dziejów Apostolskich (tamże, s. 152). Zgodnie z zasadami popularnej wówczas metody badań historii redakcji (Redaktionsgeschichte) warszawski biblista ukazuje więc, że elementy redakcyjne nie są prostymi dodatkami do starszych materiałów, ale stanowią istotny element kształtowania teologii danego dzieła.

W obszarze badań nad Ewangelią Janową ks. Feliks Gryglewicz w artykule Wkład św. Jana Ewangelisty w opracowanie rozmowy $z$ Nikodemem (CT 51[1981] fasc. 4, s. 43-64), idąc w ślady m.in. katolickiego egzegety R. E. Browna, stosuje metodę historyczno-krytyczną do badań nad czwartą Ewangelią. Lubelski biblista argumentuje, że elementy pochodzące z tradycji znajdują się głównie we wprowadzeniu do ewangelicznej perykopy J 2,23 - 3,21, a wszystko inne stanowi redakcyjne dzieło Jana w kontekście sytuacji, w której znajdował się on i jego słuchacze (tamże, s. 63). Ważne z punktu widzenia popularnej do dzisiaj hipotezy istnienia „szkoły Janowej”, nieco izolującej ją od innych nurtów nowotestamentalnej teologii, jest stwierdzenie ks. Gryglewicza, że Jan utrzymywał kontakty z innymi wspólnotami kościelnymi i korzystał z tych tradycji, które w nich wyraźniej dochodziły do głosu (tamże).

Do badań poszczególnych fragmentów czwartej Ewangelii metodą historyczno-krytyczną, z jej założeniem diachronicznego powstawania tekstów Ewangelii, ten sam autor powraca w artykule Ein rätselhaftes Fragment des 4. Evangeliums (CT 52[1982] fasc. spec., s. 125-139). W opinii lubelskiego biblisty fragment J 4,31-38 jest owocem przepracowania przez Jana materiałów tradycyjnych, po części sięgających samego Jezusa (tamże, s. 136). Takie ujęcie problemu jest dość oryginalne na tle ówczesnej biblistyki, która generalnie nie przypisywała czwartej Ewangelii większego znaczenia w rekonstrukcji autentycznych słów Jezusa.

Również w artykule Dyskusja Jezusa (J 8, 12-59) (CT 53[1983] fasc. 1, s. 29-42) lubelski biblista stosuje metodę historyczno-krytyczną do badań nad czwartą Ewangelią. W jego opinii autentyczne słowa Jezusa odnosiły się przede wszystkim do Jego relacji z Ojcem, 
zaś dyskusje z Żydami są efektem pracy redakcyjnej ewangelisty (tamże, s. 42).

W krótkim artykule Konstitutive Elemente des christlichen Lebens nach dem hl. Johannes (CT 53[1983] fasc. spec., s. 167-175) ks. Teofil Herrmann CM podkreśla natomiast związek wiary i miłości w teologii Janowej. Analiza lazarystowskiego biblisty jest z konieczności dość powierzchowna, ale zwraca on uwagę na podobny związek w nauczaniu św. Pawła, co jest wartościowe na tle niektórych ujęć, izolujących teologię Janową od innych nurtów teologii Nowego Testamentu (tamże, s. 175).

Ksiądz Stanisław Rabiej w artykule „Ego eimi” w Ewangelii św. Jana znakiem boskiej godności Jezusa (CT 58[1988] fasc. 2, s. 19-27) omawia biblijną formułę ,Ja jestem” z punktu widzenia dogmatyka, bazując w części nowotestamentalnej na pracach biblistów polskich i zagranicznych. Nie wnosi on więc własnego wkładu do biblistyki Nowego Testamentu.

W krótkim artykule Spiritus Paraclitus (CT 59[1989] fasc. 2, s. 35-42) ks. Roman Karwacki analizuje znaczenie określenia „Paraklet" w czwartej Ewangelii. Siedlecki biblista inspiruje się przy tym encykliką Jana Pawła II Dominum et vivificantem oraz pracami współczesnych dogmatyków, w obszarze badań nad Nowym Testamentem pozostając zasadniczo na płaszczyźnie korzystania z introdukcji i słowników biblijnych (tamże, s. 35).

Natomiast artykuł bp. Kazimierza Romaniuka „Jezus i jawnogrzesznica" (J 7, 53 - 8, 11) (CT 59[1989] fasc. 4, s. 5-14) poświęcony jest fragmentowi Ewangelii Janowej, który dość rzadko omawiany jest we współczesnej biblistyce z powodu wątpliwego statusu w krytyce tekstu. Warszawski biblista argumentuje jednak za pomocą metody badania historii tradycji (Traditionsgeschichte), że na podstawie kilku wczesnopatrystycznych przekazów da się odtworzyć wczesną, przed-Janową postać tego fragmentu (tamże, s. 5-10). Sugeruje poza tym wbrew stanowisku wpływowego badacza amerykańskiego Barta D. Ehrmana - że perykopa o jawnogrzesznicy została przesunięta do czwartej Ewangelii z Ewangelii Łukaszowej i że odnosi się ona 
do autentycznego wydarzenia z życia historycznego Jezusa (tamże, s. 12-13).

W badaniach nad Ewangeliami widać więc w tym okresie szczególne zainteresowanie problemem synoptycznym, Ewangelią Mateuszową oraz Ewangelią Janową.

W obszarze badań nad Corpus Paulinum w artykule Badania nad napomnieniami moralnymi św. Pawła w XX wiek" (CT 53[1983] fasc. 2, s. 47-64) ks. Lech Stachowiak dokonuje skrótowego przeglądu współczesnych badań nad parenezami Pawłowymi. Łódzki biblista zwraca uwagę na znaczenie analizy prowadzonych metodą historii form (tamże, s. 49-57), ale też - co ważne - na ich ograniczenia (tamże, s. 57). Istotny nie tylko dla ówczesnej biblistyki jest również przegląd badań nad relacją między parenezami Pawłowymi a tekstami qumrańskimi (tamże, s. 60-63), niestety, w owym czasie znanymi głównie tylko z pierwszej groty w Qumran. Artykuł opublikowany został w wersji niemieckojęzycznej w CT 53(1983) fasc. spec., s. 177-194.

W krótkim artykule Przybrane synostwo Boże w Rz 7-8 (CT 55[1985] fasc. 2, s. 19-27) ks. Jan Stępień omawia tytułowy problem w kontekście napięcia między wewnętrznym konfliktem między ciałem a duchem (Rz 7,14-25) a oczekiwaniem chwały synów Bożych (Rz 8,19-22). Podejście warszawskiego biblisty jest ciekawym przykładem ujęcia problemu teologicznego na tle analizy wewnętrznych napięć utworu, a jednocześnie w kontekście nauczania Jana Pawła II na temat cierpienia w niedawno ogłoszonym liście apostolskim Salvifici doloris z 1984 r. Tego rodzaju podejście teologiczne jest godne pochwały zarówno jako wartościowe naukowo jak i aktualne pastoralnie.

Problematyce antropologicznej poświęcony jest artykuł bp. Kazimierza Romaniuka ,Uwielbiajcie Boga w waszym ciele” (1Kor 6,20) (CT 56[1986] fasc. 4, s. 5-27). Warszawski biblista zawiera w nim analizy biblijnych tekstów dotyczących rytualnej i moralnej czystości ciała. Ponieważ artykuł jest zapisem wykładu wygłoszonego na spotkaniu chorych, bp Romaniuk dodaje na końcu krótki passus dotyczący cierpienia (tamże, s. 18-19). Szkoda, że ten wątek nie został rozwinięty głębiej, jako że w coraz bardziej popularnej teologii 
charyzmatycznej, omawianej chociażby w artykule ks. Dominika Tomczyka w tym samym zeszycie CT 56(1986) fasc. 4, s. 61-67, uwielbianie Boga w ludzkim ciele jest w bardzo niewielkim stopniu łączone z kwestią przeżywania cierpienia.

Do badań nad tematyką nierozerwalności małżeństwa w nauczaniu Nowego Testamentu powraca ks. Jan Załęski w artykule Problem „wyjatku” w 1Kor 7,15-16 (CT 53[1983] fasc. 1, s. 43-63). Warszawski biblista analizuje patrystyczne interpretacje „,przywileju Pawłowego” i stawia tezę, że należy interpretować go - wbrew nauczaniu Ojców (poza Ambrozjastrem) i tradycji prawnej Kościoła - w kategoriach przyzwolenia jedynie na separację, a nie na rozwód i powtórne małżeństwo (tamże, s. 57-60).

Po pierwszym artykule s. Teresy Czekały z 1971 r., krótki tekst s. Ewy Józefy Jezierskiej OSU „Być z Chrystusem” zaraz po śmierci (CT 55[1985] fasc. 1, s. 29-36) jest drugim artykułem nowotestamentalnym w „Collectanea Theologica”, który został napisany przez kobietę, siostrę zakonną. Mimo posoborowej odnowy teologii trzeba było więc czekać aż czternaście lat, aby kolejna kobieta i siostra zakonna zabrała naukowy głos w biblistyce Nowego Testamentu. Wrocławska urszulanka poświęca swój tekst św. Pawłowi, a konkretnie eschatologii zawartej w Flp 1,23 i 2 Kor 5,8. Optuje przy tym za koncepcją „pośredniego” stanu wspólnoty z Chrystusem, różnego od czyśćca, między męczeńską śmiercią wierzącego a paruzją (tamże, s. 34).

W krótkim artykule ,Żyjemy dla Pana, umieramy dla Pana...” (CT 59[1989] fasc. 3, s. 27-33) ta sama biblistka kontynuuje swe badania nad chrystocentryczną teologią Pawłową, skupiając się tym razem na zagadnieniu proegzystencji chrześcijanina w 2Kor 5,15 i Rz 14,7-8. Artykuł wrocławskiej urszulanki stanowi ciekawy przyczynek w budowaniu odnowionej polskiej teologii posoborowej.

Ksiądz Tomasz Horak w artykule Eschatologia Listu do Hebrajczyków (CT 59[1989] fasc. 2, s. 5-20) ukazuje tytułowe zagadnienie, opierając się na analizie głównych pojęć związanych w liście z eschatologią. Wrocławski biblista wskazuje, że w porównaniu z eschatologią Pawłową eschatologia Listu do Hebrajczyków jest bardziej 
wyważona, zwłaszcza w kwestii czasu oczekiwanej paruzji (tamże, s. 19). Nie podejmuje jednak próby porównania doktryny listu do Hebrajczyków z innymi nurtami po-Pawłowej eschatologii Nowego Testamentu, zwłaszcza z eschatologią Łukaszową.

W sferze badań nad Listami katolickimi ks. Roman Bartnicki w artykule Problem autorstwa Listu Jakuba (CT 50[1980] fasc. 4, s. 61-72) relacjonuje różne poglądy na tytułowy problem. Warszawski biblista nie daje własnej odpowiedzi na tę kwestię, ostrożnie optując jednak za hipotezą chrześcijańskiej pseudonimii (tamże, s. 71).

W artykule Postuszeństwo władzy świeckiej wedtug 1Pt 2, 13-17 (CT 54[1984] fasc. 4, s. 39-50) ks. Jan Załęski odchodzi natomiast od swych dotychczasowych zainteresowań problematyką nierozerwalności małżeństwa, by zająć się tytułowym zagadnieniem moralnym, niezwykle ważnym z punktu widzenia polskiej sytuacji moralno-społecznej roku 1984, z więc roku m.in. zamordowania ks. Jerzego Popiełuszki. Warszawski biblista konkluduje swe rozważania dość ostrożnymi słowami: „Piotr zachęca do posłuszeństwa władzy świeckiej i zachowuje dystans od kultu cesarza" (tamże, s. 49). Artykuł opublikowany został w wersji włoskojęzycznej w CT 55(1985) fasc. spec., s. 153-162.

Na kanwie encykliki Jana Pawła II z 1982 r. o godności pracy ludzkiej (Laborem exercens) powstaje biblijno-teologiczny artykuł ks. Jan Stępnia Biblijna wizja pracy ( CT 54[1984] fasc. 1, s. 45-56). W jego nowotestamentalnych partiach warszawski biblista dość tradycyjnie ukazuje pracę nie tylko jako moralny obowiązek człowieka (tamże, s. 48-49), ale także jako uczestnictwo w dziele odkupienia (tamże, s. 54-55).

O próbach odnowienia eklezjologii i biblistyki w Polsce świadczy także artykuł ks. Stanisława Haręzgi Eklezjotwórcza funkcja Słowa Bożego wedtug Dz 3,22-23 (CT 54[1984] fasc. 3, s. 30-38). Przemyski biblista przeprowadza klasyczną analizę tytułowego tekstu w kategoriach językowo-stylistycznych i egzegetycznych, by następnie wyciągnąć wnioski teologiczne o roli słowa Bożego w budowaniu Kościoła (tamże, s. 38). 
W pierwszych latach papieskiej posługi Jana Pawła II trudno więc doszukać się istotnego wpływu tej nowej rzeczywistości eklezjalnej na treść publikowanych w „Collectanea Theologica” artykułów. Wpływ ten ujawnia się dopiero po kilku latach nauczania papieża-Polaka. Jego encykliki i adhortacje stają się impulsem do badań teologiczno-biblijnych nad omawianymi w nich tematami.

\section{Zainteresowania judaizmem i tematami pokrewnymi w czasie odzyskanej wolności (1990-1999)}

Duży wpływ na publikacje biblistyczne w „Collectanea Theologica" miała zmiana na stanowisku redaktora naczelnego, którym od października 1989 r. został biblista ks. Waldemar Chrostowski. Spowodowało to bardzo widoczny wzrost liczby publikacji poświęconych judaizmowi i dialogowi chrześcijańsko-żydowskiemu. Publikacje dotyczące wprost Nowego Testamentu były natomiast z początku efektem kontynuacji badań prowadzonych w poprzednim okresie.

W nurt badań nad Nowym Testamentem w kontekście dialogu chrześcijańsko-judaistycznego wpisuje się w pewien sposób krótki artykuł ks. Waldemara Rakocego CM Elementy argumentacji rabinackiej w Rz 9,6-29 (CT 63[1993] nr 3, s. 97-102). Lazarystowski biblista podkreśla zwłaszcza obecność w Pawłowym tekście elementów charakterystycznych dla rabinackich „midraszim”.

Podobne nastawienie ideowe ma obszerny artykuł Michała Czajkowskiego (od 1994 r. przy autorach publikacji nie pojawia się już skrót „ks.” itp.) Spór o szabat. Struktura kerygmatyczna Mk 2, 23-28 (CT 64[1994] nr 1, s. 35-54). Zupełnie inne jest tu jednak podejście metodologiczne. Warszawski biblista stosuje do analizy tytułowego tekstu klasyczną metodę historyczno-krytyczną, rekonstruując we wstecznym porządku chronologicznym redakcję Marka, redakcję przed-Markową i Sitz im Leben Jezusa, a następnie w naturalnym porządku chronologicznym kerygmat Jezusa, kerygmat wspólnoty i kerygmat ewangelisty. Nie daje jednak żadnego podsumowania swych wywodów. 
W nurt badań nad Nowym Testamentem w kontekście dialogu chrześcijańsko-judaistycznego bardzo wyraźnie wpisuje się także artykuł tegoż autora Czy jest antyżydowska Ewangelia najbardziej żydowska? (CT 64[1994] nr 2, s. 43-52). Paradoksalnie sformułowany tytuł odnosi się do problemu antyżydowskiego nastawienia Ewangelii Mateuszowej. Warszawski biblista twierdzi, wbrew opiniom wielu współczesnych egzegetów, ale też w zgodzie z opiniami wielu innych współczesnych badaczy, że nastawienie to jest antyżydowskie tylko pozornie (tamże, s. 52).

Ideowo zbliżony jest przetłumaczony na język polski artykuł Barta Koeta z Amsterdamu Poglądy św. Łukasza na Żydów - odrzucenie czy polemika? (CT 64[1994] nr 2, s. 53-66), analizujący tytułowe zagadnienie na przykładzie tekstu Dz 13,46-47. Autor argumentuje, że poglądy św. Łukasza na Żydów nie stanowiły ich odrzucenia, ale przypominały wewnątrzżydowskie dyskusje rabinackie (tamże, s. 66). Znów szkoda, że dobry skądinąd holenderski biblista nie odwołał się w swych rozważaniach do tła Pawłowego i qumrańskiego, co znacznie podniosłoby poziom jego analiz. Potwierdza się więc teza, że publikowanie tekstów autorów zagranicznych nie powoduje automatycznie wzrostu ogólnego poziomu naukowego czasopisma.

Podobny charakter ideowy ma obszerny artykuł Stanisława Mędali CM Funkcja „Żydów” w Ewangelii św. Jana (CT 64[1994] nr 2, s. 79-101). Na podstawie analizy literackiej, retorycznej i historycznej tytułowego zagadnienia warszawski lazarysta twierdzi, że Jan nie napisał Ewangelii przeciw Żydom, ale po to, by jej odbiorcy trwali w swej chrześcijańskiej wierze (tamże, s. 101).

Artykuł Michała Wojciechowskiego Church as Israel according to the Revelation of St. John (CT 64[1994] fasc. spec., s. 33-40) jest kolejną publikacją w „Collectanea Theologica” dotyczącą relacji chrześcijańsko-żydowskich. Biblista uzasadnia bowiem publikację swej analizy nie tyle jej nowatorstwem, ile jej znaczeniem dla tych właśnie relacji (tamże, s. 38). Argumentuje, że ukazane w Nowym Testamencie konflikty z Żydami dotyczą w istocie wewnętrznych dysput w religii żydowskiej (tamże, s. 40). Wydaje się jednak, że teza Wojciechowskiego, iż ten sam tłum zbawionych jest opisany 
jako Izrael i jako wielki tłum sług Baranka (tamże, s. 34-35, 40) jest zbytnim uproszczeniem, nie oddającym należycie niuansów po-Pawłowej i po-Łukaszowej teologii autora Apokalipsy, wyraźnie rozróżniającej Kościół z Izraela (144 tys. opieczętowanych) i Kościół z pogan (wielki tłum ze wszystkich narodów) w ich eklezjalnej korelacji, dystynkcji i następstwie.

Do badań nad pochodzeniem Ewangelii powraca w tym czasie ks. Roman Bartnicki w dość obszernym artykule Pochodzenie Ewangelii synoptycznych $w$ świetle tradycji starożytnego Kościoła (CT 62[1992] nr 4, s. 25-43). Tekst ten można uznać za kontynuację badań warszawskiego biblisty nad różnymi rozwiązaniami problemu synoptycznego, w tym tzw. hipotezą dwóch Ewangelii, mocno odwołującą się do świadectw patrystycznych (zob. CT 59[1989] nr 3, s. 5-25). Omawiając tzw. świadectwo Papiasza, warszawski biblista zauważa, że brakowi uporządkowania u Marka przeciwstawia ono porządek Mateusza (tamże, s. 31). Nie poddaje jednak analizie łączącego obie wypowiedzi spójnika oun (,więc”), sugerującego, że Ewangelia Mateuszowa powstała w odpowiedzi na pewne braki Ewangelii Marka.

Kolejny obszerny artykuł tegoż autora nosi tytuł Badania nad ustna tradycją synoptyczna (CT 63[1993] nr 1, s. 21-52). Stanowi on rzetelne omówienie ówczesnego stanu badań nad Ewangeliami, prowadzonych metodą badania historii tradycji (Traditionsgeschichte). Ze swej strony podkreśla znaczenie hipotezy tradycji ,pielęgnowanej”, dość wiernie przekazującej naukę Jezusa (tamże, s. 51).

Krótki artykuł Mariusz Rosika Relacja Mk-Mtw świetle wspótczesnych ujęć teorii dwóch źródet (CT 66[1996] nr 4, s. 53-60) opisuje natomiast ówczesny stan badań nad problemem synoptycznym z punktu widzenia hipotezy dwóch źródeł. Praca wrocławskiego biblisty jest o tyle istotna, że hipotezę dwóch źródeł zwykle przedstawia się w biblistyce w jej klasycznej postaci, nieodpowiadającej adekwatnie na wiele argumentów przeciwko niej. Ksiądz Rosik twierdzi wprawdzie, że atutem tej hipotezy jest unikanie przyjmowania dużej liczby źródeł (tamże, s. 60), zarazem jednak opisuje hipotezy istnienia rozmaitych źródeł dodatkowych, różnych wersji typu Proto-Mk i Deutero-Mk (tamże, s. 55-58). 
Obszerny artykuł Ryszarda Zawadzkiego Antytezy Kazania na Górze (Mt 5,21-48) we współczesnej egzegezie (CT 68[1998] nr 1, s. 23-68) jest kolejnym artykułem, który ukazuje polskiemu czytelnikowi międzynarodowy stan badań w danej kwestii. Lubelski biblista staje przy tym na stanowisku, że zaostrzenie Tory jest jedynie „skutkiem ubocznym" antytez, których głównym celem jest odniesienie Prawa do woli Bożej i najdoskonalej ją wyrażającego przykazania miłości (tamże, s. 58).

Mieczysław Mikołajczak w artykule Il messaggio della parabola del figlio prodigo (Lc 15,11-32) (CT 69[1999] fasc. spec., s. 37-58) omawia natomiast tytułową perykopę w aspekcie pragmatycznym zwrócenia się do Ojca, świadomości siebie, działania i poznania (tamże, s. 57-58).

Krótki tekst świeckiego teologa Michała Wojciechowskiego Nowsze studia nad tekstem Dziejów Apostolskich (CT 64[1994] nr 1, s. 55-62) jest znowu typowym artykułem omownym, dotyczącym aktualnego stanu badań. Warszawski biblista wspiera w nim hipotezę Łukaszowego autorstwa dłuższego tekstu Dziejów Apostolskich, a więc także pierwotnego pluralizmu tekstualnego Łukaszowego utworu (tamże, s. 59-60).

Podobnie krótki artykuł Waldemara Rakocego CM Struktura literacka Dz Ap 12,1-19 (CT 64[1994] nr 4, s. 39-45) wpisuje się w nurt popularnych zwłaszcza w biblistyce francuskiej i belgijskiej strukturalistycznie (wg szkoły R. Meyneta z Gregoriany: retorycznie) ukierunkowanych badań nad tekstami biblijnymi. Artykuł ten jest przykładem coraz szybszego w owym okresie przenoszenia idei i metod badawczych z rzymskich uczelni papieskich na grunt polski.

Badania nad czwartą Ewangelią są w owym okresie znacznie mniej intensywne. Krótki artykuł Stanisława Pisarka Uczeń i jego radość w perykopie o winnym krzewie J 15,1-11 (CT 68[1998] nr 4, s. 21-29) interpretuje tytułowy temat radości na tle innych tekstów Starego Testamentu i czwartej Ewangelii. Katowicki biblista podkreśla przy tym chrystocentryczny charakter owej radości (tamże, s. 29).

Krzysztof Kościelniak z Krakowa w artykule Sąd Ducha Świętego - egzegeza i teologia J 16, 8-11 (CT 69[1999] nr 4, s. 5-21) analizuje 
zaś tytułowy tekst, przywołując jego interpretacje dokonane przez autorów z różnych epok.

W badaniach nad teologią Pawłową Andrzej Gieniusz w artykule

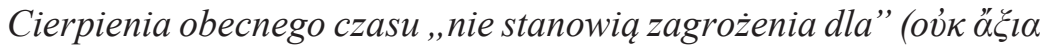

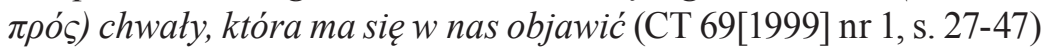
omawia trudności egzegetyczne tekstu Rz 8,18-30. Rzymski zmartwychwstaniec analizuje go strukturalistyczną metodą retoryczną, wypracowaną przez profesora Biblicum J.-N. Alettiego, co znowu świadczy o szybkim przenikaniu do biblistyki polskiej metod egzegetycznych stosowanych na uczelniach papieskich. Polski biblista stawia przy tym tezę, że cierpienie staje się dla wierzących miejscem zwycięstwa i doświadczenia potęgi miłości (tamże, s. 45).

Tekst Stanisława Bieleckiego Kairos chrześcijanina wedtug Rz 13, 11-14 (CT 65[1995] nr 3, s. 85-99) stanowi zaś przyczynek do budowania polskiej teologii czasu. Kielecki autor proponuje w nim opisywanie chrześcijańskiego przeżywania czasu właśnie w kategoriach tytułowego biblijnego kairos (tamże, s. 99). Znamienna dla rozwoju polskiej teologii jest tu propozycja stosowania greckiego pojęcia bez tłumaczenia go na język polski, co zakłada duże ubiblijnienie myśli teologicznej polskich odbiorców tekstu.

Do relacji między kobietami a mężczyznami wraca Jan Załęski w artykule Czy kobiety powinny milczeć w Kościele? (1Kor 14, 34-35) (CT 67[1997] nr 4, s. 5-20). Warszawski biblista przyjmuje opinię, że nakaz milczenia motywowany jest niedostatecznym przygotowaniem kobiet do przemawiania publicznie (tamże, s. 19), nie analizując jednak w adekwatny sposób znaczenia podobnych nakazów w 1Kor 14,28.30.

Artykuł s. Józefy Ewy Jezierskiej OSU Nadzieja chrześcijańska w teologii Pawłowej (CT 62[1992] nr 1, s. 31-41) stanowi kolejny wyraz naukowych zainteresowań tej biblistki teologią Pawłową. Wrocławska urszulanka rozwija swe wcześniejsze myśli, stwierdzając, że Kościół nie tylko proegzystuje dla Pana i jest dla świata, ale też jest przeciw grzechowi, złu i niesprawiedliwości w tym świecie (tamże, s. 38). Takie ujęcie jest istotną korektą dość optymistycznego, 
zwłaszcza we wczesnej teologii posoborowej, opisu relacji między Kościołem a światem.

Ważne miejsce wśród publikacji odnoszących się w „Collectanea Theologica" do Nowego Testamentu ma przetłumaczony na język polski artykuł Petera J. Tomsona z Amsterdamu Tradycje Jezusowe a chrystologia Pawta Apostoła (CT 63[1993] nr 2, s. 27-43). Holenderski autor szeroko znany jest ze swych publikacji dotyczących styku wczesnego chrześcijaństwa i judaizmu, m.in. stosunku Pawła do żydowskiego Prawa. Szkoda więc, że w tym artykule nie odnosi się wcale do szeroko już wówczas dyskutowanych tekstów qumrańskich, mających ogromne znaczenie do zrozumienia tej relacji. Przykład ten pokazuje, że samo otwarcie się polskiej biblistyki na współpracę z ośrodkami zachodnimi nie gwarantuje automatycznie dobrej jakości efektów pracy.

Obszerny artykuł Piotra R. Gryźca OFMConv Tytuły chrystologiczne w Listach Pasterskich (CT 66[1996] nr 3, s. 5-30) przedstawia dość tradycyjną analizę semantyczną owych tytułów, wywodzącą się ze szkoły lubelskiego biblisty o. Hugolina Langkammera OFM. $\mathrm{Na}$ podkreślenie zasługuje natomiast wychwycenie przez autora zróżnicowania omawianej tytulatury w poszczególnych Listach Pasterskich (tamże, s. 29), co nie zawsze było czynione w ówczesnej biblistyce, generalnie traktującej Listy Pasterskie jako zbiór jednorodny wewnętrznie.

Artykuł Tomasza Horaka Teologia wiary w Liście do Hebrajczyków (CT 61[1991] nr 1, s. 49-62) jest owocem dalszych badań tegoż autora nad Listem do Hebrajczyków. Metoda badań także zbliżona jest do tej zastosowanej w CT 59(1989) nr 2, s. 5-20. Metodycznie i teologicznie zbliżonymi tekstami tegoż autora są również jego artykuły Eklezjologia Listu do Hebrajczyków. Szkic teologiczny (CT 61[1991] nr 1, s. 49-62) oraz Chrystologia Listu do Hebrajczyków (CT 62[1992] nr 4, s. 45-57).

Artykuł Andrzeja Kiejzy OFMCap Charakter obecności Chrystusa w Kościele wedtug Ap 1,12-20 (CT 65[1995] nr 4, s. 21-37) to przykład sporego zainteresowania polskich biblistów księgą Apokalipsy. W celu sformułowania tez teologicznych kapucyński biblista 
przeanalizował funkcję języka symbolicznego i elementy teologii obrazu w badanym tekście. Świadczy to o stopniowym uwalnianiu się polskiej biblistyki ze stosowania metody historyczno-krytycznej na rzecz nowszych ujęć, nierzadko bardziej adekwatnych do badania analizowanych tekstów.

Nieco mniejsze znaczenie ma wspomniane wyżej podejście metodologiczne w artykule tegoż autora Postać Baranka w Ap 6,1 i 6, 16-17 na tle antropomorficznego obrazu Boga w Nowym Testamencie (CT 66[1996] nr 3, s. 31-42).

W artykule Hermeneutyka Apokalipsy - kilka przydatnych uściśleń (CT 69[1999] nr 4, s. 23-38) ten sam autor zwraca uwagę na język, styl, symbolikę i kierunki interpretacji Apokalipsy. Optuje przy tym za pojmowaniem Apokalipsy w kategoriach natchnionej księgi dziejów ludzkości, a jej symboli - w kategoriach nośników treści ponadczasowych (tamże, s. 37).

$\mathrm{Z}$ kolei artykuł warszawskiego teologa prawosławnego Henryka Paprockiego Elementy liturgii starotestamentalnej w Nowym Testamencie (CT 64[1994] nr 2, s. 103-110) zwraca uwagę na obecność w Nowym Testamencie elementów znanych także z Talmudu i innych tekstów żydowskich. Nie przeprowadza jednak analizy historii tradycji tych motywów, apriorycznie zakładając, że kierunek jej przepływu musiał być jeden: od judaizmu do chrześcijaństwa.

Nowym, ważnym elementem w zamieszczanych w „Collectanea Theologica" publikacjach nowotestamentalnych, w kontekście coraz bardziej fragmentaryzującej się biblistyki polskiej, jest opracowanie Mirosława Kiedzika z Warszawy Ewangelia i Dzieje Apostolskie św. Łukasza - bibliografia publikacji w Polsce za lata 1986(85)-97 (CT 69[1999] nr 4, s. 117-138).

Upadek komunizmu i przynajmniej częściowe odzyskanie politycznej wolności w 1989 r. nie odbiły się więc początkowo na treści i poziomie publikacji nowotestamentalnych w „Collectanea Theologica”. Od strony negatywnej zauważyć można zaprzestanie publikowania od 1989 r. - wbrew odzyskiwaniu pozycji Polski w świecie - obcojęzycznych numerów specjalnych, które zawierały wartościowe artykuły polskich teologów, także nowotestamentalistów. 
Numery specjalne opublikowano tylko okazjonalnie w latach: 1994, 1998, 1999, 2001, 2004 i 2007.

Powierzenie funkcji redaktora naczelnego ks. Waldemarowi Chrostowskiemu wpłynęło natomiast na liczbę artykułów odnoszących się w „Collectanea Theologica” do Nowego Testamentu pośrednio, przez perspektywę badań nad dialogiem chrześcijańsko-judaistycznym. Szkoda, że w owym czasie wycofał się z publikowania artykułów w „Collectanea Theologica” inny warszawski biblista, bp. Kazimierz Romaniuk. Pozytywnym elementem jest natomiast fakt, że artykuły nowotestamentalne stały się nierzadko bardziej obszerne niż w okresie wcześniejszym.

\section{Czas uniwersyteckich dyskusji (2000-2006)}

Od jubileuszowego roku 2000 wydawanie „Collectanea Theologica" przejął powstały na bazie Akademii Teologii Katolickiej Uniwersytet Kardynała Stefana Wyszyńskiego w Warszawie. Czasopismo stało się odtąd periodykiem, w pełnym tego słowa znaczeniu, uniwersyteckim. Tematyka artykułów nowotestamentalnych była natomiast zbliżona do tej z okresu wcześniejszego.

Temat relacji chrześcijańsko-żydowskich podejmuje Stanisław Mędala w obszernym artykule „Królestwo Boże będzie wam zabrane” (Mt 21,34). Przypowieść o sprzeniewierczych dzierżawcach (Mk 12,1-12 i par.) (CT 70[2000] nr 2, s. 7-34). Warszawski biblista analizuje tytułową przypowieść za pomocą metody historyczno-krytycznej, narracyjnej i semiotycznej oraz podejść badawczych opartych na analizie żydowskich tradycji interpretacyjnych i historii oddziaływania tekstu. Świadczy to o stopniowym przyswajaniu przez polską biblistykę zachęt do pluralizmu metodologicznego, zawartych w opublikowanym w 1993 r. dokumencie Papieskiej Komisji Biblijnej o interpretacji Biblii w Kościele.

Ten sam temat zasadniczy powraca w artykule Michała Czajkowskiego „Czyż Bóg odrzucił lud swój?” (Rz 11,1) - teologia odrzucenia $i$ zastapienia Izraela (CT 70[2000] nr 2, s. 35-45). Metoda badawcza jest tu jednak zupełnie inna. Warszawski biblista analizuje bowiem 
tytułowy tekst w kontekście innych wypowiedzi Starego i Nowego Testamentu, a także w kontekście nauczania II Soboru Watykańskiego i Jana Pawła II. Jego odpowiedź na tytułowe pytanie jest negatywna (tamże, s. 45).

Do tej samej problematyki odnosi się Waldemar Chrostowski w artykule $C z y \dot{Z y d z i}$,, nie podobają się Bogu i sa wrodzy wszystkim ludziom" (1Tes 2,15)? Niewiara w Jezusa Chrystusa a wrogość wobec Niego i Jego wyznawców (CT 70[2000] nr 2, s. 47-68). Warszawski biblista bada problematyczny tekst tytułowy metodą historyczno-krytyczną i podkreśla różnicę między prostą niewiarą części Żydów w Jezusa-Mesjasza a wrogością i czynnym oporem niektórych z nich wobec Jego wyznawców (tamże, s. 68). Chrostowski w dużej mierze idzie w tym względzie za świadectwem Dziejów Apostolskich (tamże, s. 53-57, 64-66), które wszak reinterpretują Pawłowy tekst, wraz z innymi listami apostoła, w dość specyficzny sposób, generalnie ukazując odrzucenie Ewangelii przez Żydów jako warunek ewangelizacji pogan w kolejnych etapach tej misji (por. tamże, s. 66). Pawłowy tekst 1Tes 2,14-16 podkreśla natomiast rolę Judejczyków w zabiciu Jezusa i proroków, prześladowaniu wyznawców Jezusa w Judei i ściganiu Pawła za misję wśród pogan.

Do dyskusji na temat relacji między judaizmem a chrześcijaństwem, na nowo sprowokowanej dokumentem Papieskiej Komisji Biblijnej Lud żydowski i jego święte Pisma w Biblii chrześcijańskiej, powraca Mirosław Wróbel w artykule „Żydzi” w Ewangelii Janowej (CT 73[2003] nr 1, s. 19-36). Lubelski biblista ukazuje szeroki zakres znaczenia i funkcji tytułowego określenia w czwartej Ewangelii, a także analizuje dotyczące tego problemu dokumenty watykańskie.

Zbliżony tematycznie i metodologicznie jest obszerny artykuł Henryka Witczyka Przymierze zawarte na Synaju a Nowe Przymierze $w$ Chrystusie (CT 73[2003] nr 1, s. 37-72). Lubelski biblista analizuje w nim różne biblijno-teologiczne koncepcje relacji między oboma Przymierzami, skupiając się zwłaszcza na koncepcji Alberta Vanhoye z rzymskiego Biblicum oraz nowym dokumencie PKB.

Do tej samej biblijno-teologicznej problematyki nawiązują również artykuły: Waldemara Chrostowskiego Kościół a Izrael (CT 73[2003] 
nr 1, s. 73-94), Stanisława Hałasa SCJ „Uświęceni przez ofiarę Chrystusa raz na zawsze" (por. Hbr 10, 10). Rozumienie kultu w Starym i Nowym Przymierzu (CT 73[2003] nr 1, s. 95-116), Antoniego Troniny Judaizm a chrześcijaństwo w I wieku. Koegzystencja czy konfrontacja? (CT 73[2003] nr 1, s. 117-137) i Artura Maliny Jedność Bożego planu zbawienia (CT 73[2003] nr 1, s. 139-150).

Temat relacji chrześcijańsko-żydowskich podejmuje także Zdzisław Pawłowski w artykule Ojczyzna Jezusa: Ziemia i jej znaczenie w Ewangelii wg św. Marka (CT 74[2004] nr 2, s. 83-95). Analizując przestrzenny wymiar działalności Jezusa, włocławski biblista nie wchodzi głębiej w problematykę aluzyjnego i symbolicznego sensu Markowych określeń geograficznych i topograficznych.

Do tematu relacji chrześcijańsko-żydowskich powraca również Waldemar Chrostowski w artykule „Czyż Bóg odrzucił lud swój” (Rz 11,1), Refleksja biblijno-teologiczna (CT 75[2005] nr 2, s. 39-56), analizując tytułową wypowiedź w jej bezpośrednim kontekście. Warszawski biblista broni mało popularnej, niestety, we współczesnej teologii tezy, że judaizm, który rozwinął się w erze chrześcijańskiej, nie stanowi prostej kontynuacji religii Starego Testamentu, zaś jego status soteriologiczny nie wynika z trwania Izraela, ale z wierności Boga, który najpełniej objawił się w Jezusie Chrystusie (tamże, s. 55-56).

Istotnym elementem dyskusji na temat relacji chrześcijańsko-żydowskich stają się także publikacje dotyczące relacji tekstów nowotestamentalnych do pism znad Morza Martwego. W krótkim artykule Pisma qumrańskie a Ewangelia Janowa (CT 75[2005] nr 3, s. 55-61) Mirosław S. Wróbel z Lublina pobieżnie ukazuje aktualny stan badań w tej kwestii, odrzucając hipotezę bezpośredniej zależności czwartej Ewangelii od pism qumrańskich (tamże, s. 60-61).

Tej samej tematyki dotyka Anna Kuśmirek z Warszawy w artykule Pośrednik objawienia w pismach qumrańskich $i$ w czwartej Ewangelii (CT 75[2005] nr 3, s. 63-83), dochodząc do podobnych wniosków o niezależności wspólnoty Janowej od wspólnoty z Qumran (tamże, s. 82).

Zbliżoną problematykę porusza również Waldemar Chrostowski w artykule Nowy Testament a Qumran - ponad pół wieku dociekań 
i dylematów (CT 75[2005] nr 3, s. 139-158), wbrew teoriom genetycznie łączącym oba nurty słusznie wskazuje na milczenie Nowego Testamentu o ewentualnej wspólnocie qumrańskiej, ale także na dziwne milczenie qumranologów na temat Nowego Testamentu (tamże, s. 157).

Wśród tekstów poświęconych szczegółowym problemom egzegetycznym Andrzej Kowalczyk z Gdańska w artykule Próba nowej interpretacji niektórych liczb w Ewangeliach (CT 70[2000] nr 1, s. 37-49) proponuje dość oryginalne rozwiązania typologiczne i gematryczne. Nawet jeśli nie są one bardzo przekonujące, to świadczą o pewnej oryginalności polskiej myśli egzegetycznej.

W artykule Mateuszowa metaforyka światta (Mt 4,15-16; 5,14-16; 6,22-23) (CT 75[2005] nr 4, s. 35-47) Stefan Szymik z Lublina analizuje odnośne teksty i słusznie zauważa, że w Mt 5,13-16 metafora soli jest negatywną paralelą dla metafory światła (tamże, s. 40).

Do problematyki nowotestamentalnego nauczania na temat rozwodów powraca Zdzisław Żywica w artykule Kwestia listu rozwodowego w interpretacji Jezusa (Mt 5, 31-32) (CT 76[2006] nr 3, s. 19-32). Olsztyński biblista na podstawie kilku wersji nowotestamentalnych logiów Pana na ten temat rekonstruuje pierwotne słowa Jezusa w wersji greckiej (tamże, s. 24). Argumentuje też, że w kwestii rozwodów Tora Mojżesza musi ustąpić woli Bożej (tamże, s. 26).

Artykuł Mariana Machinka z Olsztyna „, Klauzula Mateuszowa” (Mt 5, 32; 19, 9) jako problem pastoralny (CT 70[2000] nr 3, s. 5-21) zawiera dość powierzchowną analizę ewangelicznych tekstów dotyczących rozwodów, skupiając się na ich interpretacji w różnych wyznaniach chrześcijańskich.

Z kolei Wojciech Michniewicz z Białegostoku w artykule $C z y$ „wypetnienie się Pism” jest właściwym znaczeniem zwrotu ,hetaire, ef' ho parei" u Mt 26,50a? (CT 70[2000] nr 1, s. 51-61) po analizie kontekstu badanej wypowiedzi udziela na tytułowe pytanie odpowiedzi pozytywnej (tamże, s. 57).

Ryszard Zawadzki w tekście „Ich sende meinen Boten vor dir Her” (Mk 1,2): die Gestalt des Elija im Markusevangelium (CT 71[2001] fasc. spec., s. 23-52) analizuje zaś Markowe teksty odnoszące się 
bezpośrednio i pośrednio do postaci Eliasza. Nie wyjaśnia jednak, dlaczego w Mk 9,4 Eliasz wymieniony został przed Mojżeszem (tamże, s. 32-33).

Dariusz Kotecki z Torunia w artykule „Nawracajcie się $i$ wierzcie w Ewangelię" (Mk 1,15) - fundament życia chrześcijańskiego (CT 72[2002] nr 3, s. 33-53) bada tytułowy tekst, opierając się na analizie jego greckich słów kluczowych: metanoein i pisteuein. Wskazuje również na aktualizację tego tekstu w niedawno opublikowanym liście apostolskim Jana Pawła II Tertio millennio adveniente (tamże, s. 53).

Artur Malina z Katowic w artykule Dobra Nowina nieupiększona. Obraz Piotra w Ewangelii Marka (CT 74[2004] nr 1, s. 21-38) stosuje do badania tytułowego zagadnienia elementy analizy narracyjnej, podkreślając chrystocentryzm prezentacji Piotra w Markowej Ewangelii (tamże, s. 38).

Mieczysław Mikołajczak w obszernym artykule Działalność

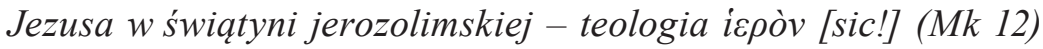
(CT 75[2015] nr 1, s. 5-45) argumentuje, że w Mk 12 ewangelista podejmuje konsekwentną krytykę judaizmu i sanktuarium jerozolimskiego, dopóki judaizm nie uwierzy w Jezusa (tamże, s. 44).

Z kolei Waldemar Rakocy z Lublina w artykule „Entos hymōn” (Łk 17,21: królestwo Boże „w was” czy „pośród was”? (CT 71[2001] nr 1, s. 31-41) wraca do swych zainteresowań dziełem Łukaszowym i opowiada się za tłumaczeniem tytułowego zwrotu jako „pośród was" (tamże, s. 40).

W artykule Il dialogo fra Gesù e il magistrato ricco in Lc 18,18-23 (CT 74[2004] fasc. spec., s. 15-48) Ryszard Zawadzki przeprowadza egzegezę tytułowego tekstu, porównując w konkluzji bogactwo zwierzchnika jako przeszkodę dla nawrócenia z bogactwem Zacheusza, podkreślającym wielkość jego nawrócenia (tamże, s. 47).

Z kolei krótki artykuł Mieczysława Mikołajczaka ze Świebodzina Królewskie wyznanie Jezusa przed Sanhedrynem (CT 70[2000] nr 3, s. 23-30), opublikowany na krótko przed rozpoczęciem w 2001 r. przygotowań do budowy świebodzińskiego pomnika Chrystusa Króla, zajmuje się kwestią intronizacji Jezusa w Łk 22,69 (tamże, s. 30). Widać 
tu więc ciekawy związek teoretycznej egzegezy Nowego Testamentu z praktycznymi działaniami pastoralnymi i architektonicznymi.

Tadeusz Mierzwa w artykule Gesù risorto l'adempimento delle Scritture e la pienezza escatologica. Analisi del brano Lc 24.44-49 (CT 71[2001] fasc. spec., s. 53-66) przeprowadza egzegezę tytułowego tekstu za pomocą analizy strukturalistycznej, nazywanej przez R. Meyneta z Gregoriany retoryczną. Jest to kolejne świadectwo przenikania metod analizy z rzymskich uczelni papieskich do biblistyki polskiej.

Andrzej Suski z Torunia w artykule Przekaz świadectwa Jana Chrzciciela w czwartej Ewangelii (CT 71[2001] nr 1, s. 91-102) analizuje tekst J 1,19-34 metodą historyczno-krytyczną, rekonstruując hipotetyczną pierwotną postać przekazu (tamże, s. 101-102).

Natomiast Krzysztof Mielcarek z Lublina w dość obszernym artykule Interpretacja frazy ,, bogami jesteście” (J 10,34) w świetle literatury Starego Testamentu i literatury międzytestamentalnej (CT 70[2000] nr 1, s. 63-85) opowiada się za hipotezą rozumienia tytułowego zdania jako odnoszącego się do ludu otrzymującego od Boga Torę pod Synajem (tamże, s. 85).

W artykule Interpretacja Janowej narracji o otwartym grobie (J 20,1-18) w świetle mitu o rajskim ogrodzie (CT 74[2004] nr 1, s. 39-63) Mariusz Rosik z Wrocławia ujmuje relację między oboma tekstami w kategoriach nie tyle świadomego literackiego wykorzystania, ile raczej możliwych powiązań w umyśle odbiorcy (tamże, s. 63).

W artykule Kontemplacja Boga w Jezusie wedtug czwartej Ewangelii (CT 70[2000] nr 4, s. 37-53) Stanisław Mędala omawia Janowe teksty związane z tematem widzenia i kontemplacji. Warszawski biblista do pewnego stopnia wpisuje się w nurt badań analizujących teksty biblijne pod kątem występowania w nich motywów sensualnych, który staje się coraz bardziej popularny we współczesnej biblistyce.

W artykule Lata wizyt Pawła w Jerozolimie po nawróceniu i rok ucieczki z Damaszku (CT 72[2002] nr 1, s. 89-98) Waldemar Rakocy mierzy się z trudnym problemem ustalenia chronologii życia Apostoła Narodów. Godny pochwały z metodologicznego punktu widzenia jest 
fakt, że lubelski biblista nie wychodzi, jak wielu uczonych, od danych znacznie późniejszych od listów Pawła i Dziejów Apostolskich, ale analizuje przede wszystkim odnośne teksty Pawłowe Ga 1-2 i 2Kor 11. Argumentuje, że nawrócenie Pawła dokonało się prawdopodobnie w 34 r., a wizyty w Jerozolimie miały miejsce w latach 37 i 51 (tamże, s. 98). Nie bierze jednak pod uwagę wzmianki o czternastu latach w 2Kor 12,2 i jej możliwej korelacji z Ga 2,1.

Kontynuacją tego artykułu jest tekst Problem datacji i kolokacji w misji Pawła tzw. Soboru Jerozolimskiego (CT 72[2002] nr 2, s. 31-44). Również tutaj Rakocy wychodzi od danych Pawłowych tekstów Ga 1,18; 2,1-10. Odważnie opowiada się za dość marginalnie traktowaną w ówczesnej, a także i współczesnej biblistyce hipotezą wydarzenia Soboru po misji Pawła w Galacji, Macedonii i Achai (tamże, s. 36-41).

Do problematyki chronologii Pawłowej ten sam autor powraca w krótkim artykule Czas powstania Drugiego Listu do Koryntian (CT 73[2003] nr 3, s. 33-40). Argumentuje, że czasem tym był rok opuszczenia przez Pawła Efezu (a więc - według innych badań lubelskiego biblisty - rok 55), najprawdopodobniej we wrześniu (tamże, s. 38-39).

Stanisław Bielecki w artykule Tło polityczne, kulturowe i społeczne perykopy o obowiąkach chrześcijanina względem społeczności świeckiej (Rz 13, 1-10) (CT 70[2000] nr 3, s. 31-51) stawia natomiast inną tezę niż ks. Załęski w artykule opublikowanym w trudnym roku 1984 (CT 54[1984] fasc. 4, s. 39-50). Kielecki biblista twierdzi bowiem, że dla adresatów Listu do Rzymian kult cesarza nie stanowił poważniejszego problemu (tamże, s. 41).

Jan Załęski w artykule Paruzja a sytuacja zmartych w Chrystusie wedtug 1Tes 4,13-18 (CT 71[2001] nr 1, s. 61-76) dotyka zaś problematyki eschatologii. Warszawski biblista sprzeciwia się traktowaniu „słowa Pana” z 1Tes 4,15 jako agrafonu, choć przyznaje, że mogło ono pochodzić z pozaewangelicznej tradycji o Jezusie (tamże, s. 72-74).

Ryszard Selejdak w artykule Koncepcja diakonatu $w$ listach św. Pawła Apostoła (CT 74[2004] nr 3, s. 61-75) analizuje tytułowe zagadnienie nie rozróżniając listów proto- i deutero-Pawłowych. 
Kontrowersyjne we współczesnej teologii, żeńskie użycie słowa diákonos w Rz 16,1 rzymski dogmatyk tłumaczy bez żadnych komentarzy jako „diakonisa” (tamże, s. 73).

Również Magdalena Tkacz w Warszawy w artykule $Z$ badań nad retoryka w listach św. Pawła (CT 71[2001] nr 1, s. 103-112) dość powierzchownie omawia niektóre aspekty retoryki Pawłowej, nie dając w swym tekście żadnych przypisów do literatury przedmiotu.

Natomiast obszerny artykuł Urszuli Topczewskiej Paulusbriefe als Diskurs. Zur pragmalinguistischen Analyse der paulinischen Texte (CT 71[2001] fasc. spec., s. 67-99) jest świadectwem stosowania w polskiej biblistyce nowych podejść badawczych, w tym przypadku - analizy pragmalingwistycznej. Autorka podkreśla, że listy Pawłowe nigdy nie były czysto prywatne, ale zawsze miały charakter oficjalny (tamże, s. 95). Sugeruje też, że listy Pawłowe tworzą nowy, chrześcijański typ dyskursu, istotnie modyfikujący dotychczasowe modele semickie i greckie (tamże, s. 95-97).

Piotr Roman Gryziec w artykule ,Zdrowa nauka” w Listach Pasterskich (CT 76[2006] nr 4, s. 5-28) analizuje znaczenie tytułowego wyrażenia. Krakowski biblista stwierdza, że odnosi się ono nie tyle do prawd dogmatycznych, ile do porządku w Kościele i cnotliwego życia w opartych na Ewangelii relacjach (tamże, s. 27).

Z kolei Bartosz Adamczewski w artykule Jakub, brat Pański, i jerozolimska wspólnota ubogich (CT 74[2004] nr 1, s. 65-82) analizuje rozmaite obrazy Jakuba w tekstach źródłowych i literaturze przedmiotu. Warszawski biblista broni tezy, że Jakub był przywódcą wspólnoty wyznawców mesjańskiego królestwa, w którym szczególny udział mają ubodzy (tamże, s. 82).

Tomasz Maria Dąbek z Krakowa w artykule Teksty eschatologiczne w Listach do siedmiu Kościołów (Ap 2-3) (CT 71[2001] nr 1, s. 19-30) przedstawia dość tradycyjną egzegezę odnośnych tekstów Apokalipsy, jednak bez wyraźnego podsumowania swych analiz.

Przyczynkiem do budowania chrystologii Nowego Testamentu jest artykuł Augustyna Jankowskiego „Mysterium incarnationis” jako poprawna i operatywna kategoria biblijna - jej geneza i etapy objawienia w Nowym Testamencie (CT 71[2001] nr 3, s. 5-15). Tyniecki 
biblista wykazuje w nim, że kategorie „wcielenia” i „misterium” stanowią pomost między tekstami nowotestamentalnymi a późniejszymi formułami dogmatycznymi (tamże, s. 15).

Tej samej problematyki dotyka artykuł Stanisława Gądeckiego „Mysterium incarnationis” wedtug pism Janowych (CT 71[2001] nr 3, s. 31-49). Poznański biblista dochodzi w nim do podobnych wniosków, rozszerzając je o aktualność tych kategorii na progu nowego tysiąclecia chrześcijaństwa, czego przykładem jest bulla Jana Pawła II Incarnationis mysterium (tamże, s. 49).

W nowotestamentalnych partiach artykułu Lekarz i jego postuga w świetle Biblii (CT 71[2001] nr 3, s. 51-67) Waldemar Chrostowski przedstawia przekrojową analizę odnośnych tekstów Nowego Testamentu. Warszawski biblista podkreśla przy tym rolę zawartej w wielu z nich subtelnej ironii, która zachęca, by na tę problematyką patrzeć z dystansem i krytycyzmem (tamże, s. 67).

Z kolei Paweł Szuppe w nowotestamentalnych partiach artykułu Szatan w Biblii (CT 75[2005] nr 1, s. 47-67) omawia teksty Nowego Testamentu dotyczące szatana, podsumowując swe analizy konkluzjami dogmatycznymi.

Natomiast Józef Kozyra z Katowic w artykule Nowe przykazanie miłości (CT 76[2006] nr 4, s. 29-45) analizuje znaczenie tytułowego wyrażenia na podstawie krótkiego przeglądu odnoszących się do niego tekstów nowotestamentalnych w ich układzie kanonicznym. Nie analizuje więc tej ważnej nowotestamentalnej idei chociażby w perspektywie jej możliwego diachronicznego rozwoju.

W pierwszych latach XXI w. wyraźnie zwiększyła się więc liczba zamieszczanych w „Collectanea Theologica” publikacji dotyczących badań nad Nowym Testamentem. Stało się to głównie za sprawą publikowania referatów z różnych sympozjów biblistycznych i teologicznych. W dalszym ciągu ważne miejsce miały zaś wśród nich konferencje poświęcone relacjom między chrześcijaństwem a judaizmem. 


\section{Czas badań nad recepcją Starego Testamentu w Nowym (2007-2015)}

Od 2007 r. w każdym czwartym numerze „Collectanea Theologica” z danego roku publikowane są referaty z organizowanych na Wydziale Teologicznym UKSW konferencji naukowych z cyklu „Orędzie, Interpretacja, Recepcja”, odnoszących się każdorazowo do określonej księgi Starego Testamentu. Artykuły nowotestamentalne $\mathrm{z}$ tego cyklu poświęcone są więc recepcji danej księgi starotestamentalnej w Nowym Testamencie.

Kwestię recepcji starotestamentalnej Księgi Ezechiela w Nowym Testamencie podejmuje artykuł Dariusza Koteckiego Księga Ezechiela w Ewangelii wedtug św. Jana na przykładzie obrazu Dobrego Pasterza (J 10) oraz , strumieni wody życia” (J 7,37-39) (CT 77[2007] $\mathrm{nr}$ 4, s. 49-77). Toruński biblista argumentuje, że enigmatyczny wers: „Rzeki wody żywej popłyną z jego wnętrza” odnosi się do Jezusa, a nie do wierzącego (tamże, s. 69). Słusznie zaznacza także, że aluzja do Ez 47,1-12 w J 7,38 jest w istocie jedynie możliwa (tamże, s. 72-76), co sugeruje, że autor czwartej Ewangelii zakładał u swoich odbiorców zdolność do dostrzegania aluzji nawet najbardziej minimalnych i subtelnych (tamże, s. 77).

Zbliżonej tematyce poświęcony jest artykuł Waldemara Linke Księga Ezechiela w Apokalipsie wedtug św. Jana (CT 77[2007] nr 4, s. 79-101). Warszawski biblista stawia ciekawą tezę o częściowym paralelizmie struktury Księgi Ezechiela i Apokalipsy (tamże, s. 88-89), nie odnosząc się jednak do wcześniejszej publikacji niemieckiej biblistki polskiego pochodzenia, Beate Kowalski, na ten temat.

Pokłosiem biblijnej konferencji poświęconej Pieśni nad Pieśniami jest obszerny artykuł Waldemara Linke Pieśń nad Pieśniami w Apokalipsie? Aluzja literacka lub zbieżność wyrazowa w badaniach intertekstualnych (CT 78[2008] nr 4, s. 71-103). Warszawski biblista w rzetelny sposób omawia coraz mocniej dyskutowany we współczesnej biblistyce problem metodologii badań intertekstualnych, analizując współczesne koncepcje dotyczące tej kwestii i wskazując na problematyczność ograniczeń nakładanych na to podejście 
w dokumencie PKB o interpretacji Biblii w Kościele (tamże, s. 82-83). Ukazuje także szanse, jakie lektura intertekstualna stwarza dla egzegezy, nie negując zasadności innych metod i podejść interpretacyjnych (tamże, s. 103).

W artykule Księga Kapłańska w Nowym Testamencie (CT 80[2010] nr 4, s. 135-154) Dariusz Kotecki z Torunia podkreśla aktualność obecnego w Księdze Kapłańskiej wezwania do świętości i do miłości bliźniego (tamże, s. 154).

Ten sam autor w artykule Ksiega Nahuma w Nowym Testamencie (CT 81[2011] nr 4, s. 121-135) zwraca uwagą na prawdopodobną obecność aluzji do Księgi Nahuma zwłaszcza w Księdze Apokalipsy.

Warszawska biblistka protestancka Kalina Wojciechowska w artykule Nowa świątynia u progu nowej ery. Sposoby obecności Księgi Aggeusza w Nowym Testamencie (CT 82[2012] nr 4, s. 99-112) dzieli tytułowe sposoby obecności na kryptocytat i aluzje. Wskazuje przy tym na transformacje pierwotnego sensu tekstów przez wyodrębnienie poszczególnych obrazów i zwrotów jako nowych jednostek znaczeniowych oraz modyfikację ich kontekstów, a przez to wprowadzenie nadwyżki znaczeniowej i interpretację przez peszeryzację (tamie, s. 112).

Owocem konferencji biblistycznej na temat Księgi Rodzaju jest artykuł Bartosza Adamczewskiego Koniec teorii źródeł? Genealogie $R d z$ 4,17 - 5,32 i ich przepracowanie w Nowym Testamencie (CT 83[2013] nr 4, s. 47-74). Warszawski biblista kwestionuje w nim wartość bardzo rozpowszechnionych we współczesnej biblistyce teorii źródeł, zarówno w Pięcioksięgu (J, P itp.), jak i w Ewangeliach synoptycznych (Q). W miejsce nowotestamentalnej teorii ,źródła Q” proponuje hipotezę przepracowania żydowskiej Apokalipsy Tygodni w genealogii Łk 3,23-38 oraz hipotezę Mateuszowej zależności od Ewangelii Łukasza.

Ten sam autor w nowotestamentalnej części artykułu Uniwersalistyczna perspektywa Księgi Jozuego w Starym i Nowym Testamencie (CT 84[2014] nr 4, s. 105-129) kwestionuje dość powszechnie przyjmowaną we współczesnej biblistyce interpretację Listu Jakuba jako pisma anty-Pawłowego. Argumentuje, że List Jakuba jest jedynie 
pozornie anty-Pawłowy, a w gruncie rzeczy jest pro-Pawłowy, przez zastosowanie w nim do kreowania obrazu Jakuba retorycznych technik èthopoiia, eirōneia i anaskeuē (tamże, s. 118-128).

W obszarze badań nad samym Nowym Testamentem artykuł Janusza Kręcidły Dlaczego Jezus jest godzien najwyższej czci? Strategie perswazyjne ewangelistów Mateusza i Łukasza w perspektywie kultury honoru i wstydu (CT 80[2010] nr 2, s. 5-20) ukazuje wartość rzadko dotąd stosowanego $\mathrm{w}$ polskiej biblistyce podejścia antropologiczno-kulturowego, rozwijanego zwłaszcza w biblistyce amerykańskiej. Warszawski biblista zwraca uwagę na intrygujące podobieństwo strategii perswazyjnych obu ewangelistów (tamże, s. 20), choć w tradycyjnej biblistyce są oni traktowani jako należący do dwóch wyraźnie różnych sfer kulturowych: judeo- i poganochrześcijańskiej.

W artykule „Oto wasz dom pozostawiony jest wam pusty” (Mt 23,38). Mateuszowa interpretacja losów jerozolimskiej świątyni Jahwe Izraela (CT 79[2009] nr 2, s. 33-50) Zdzisław Żywica z Olsztyna przeprowadza egzegezę tekstu Mt 23,1 - 24,2, formułując dość ryzykowną tezę, że rozejście się dróg judaizmu i judeochrześcijaństwa spowodowane było zniszczeniem świątyni w 70 r. (tamże, s. 50).

W tekście Judasz - sprawiedliwy Starego Testamentu (CT 77[2007] nr 1, s. 57-68) Wojciech Stabryła analizuje Mateuszową perykopę traktującą o śmierci Judasza (Mt 27,3-10). Toruński biblista stawia ciekawą tezę, że powieszenie się Judasza było wymierzeniem sobie, jako fałszywemu świadkowi powodującemu ukrzyżowanie Jezusa, sprawiedliwej kary przewidzianej w takiej sytuacji w Pwt 19,16-19; 21,22-23, a więc również powieszenia na drzewie (tamże, s. 66-67).

Mieczysław Mikołajczak z Poznania w krótkim artykule Relacja „o prawdziwych krewnych Jezusa” (Mk 3,31-35) (CT 82[2012] nr 2, s. 49-58) przeprowadza egzegezę tytułowego tekstu, w tym przypadku nie podejmując analizy jego problematycznego znaczenia dla katolickiej mariologii.

Ten sam autor podejmuje problematykę mariologiczną w artykule Obraz Maryi w perykopie o pobycie Jezusa w Nazarecie (Mk 6,1-6) (CT 82[2012] nr 3, s. 29-40). Poznański biblista analizuje tytułową kwestię dość powierzchownie, jedynie mimochodem wspominając 
o problemie interpretacji braci i sióstr Jezusa (tamże, s. 40 n., 31) oraz braku czci ze strony nie tylko Jego krewnych, ale także Jego domu (tamże, s. 36-37).

Ten sam biblista w artykule Biblijna interpretacja tajemnicy Wcielenia (Łk 1,26-38) (CT 81[2011] nr 2, s. 49-69) przeprowadza egzegezę tytułowego tekstu i jego znaczenia mariologicznego na tle starotestamentalnym, nie analizując jego możliwych aluzji do tekstów Pawłowych (Rz 1,1-4 itp.).

W krótkim artykule Świątynia jerozolimska i jej znaczenie w kształtowaniu obrazu relacji Kościół - Izrael w Dwudziele św. Łukasza (Łk-Dz) (CT 81[2011] nr 3, s. 5-16) ten sam autor analizuje tytułowe zagadnienie, dość synonimicznie używając określeń ,judaizm” i „Izrael” (tamże, s. 15), co wydaje się błędem z punktu widzenia subtelnej, po-Pawłowej teologii Łukaszowej.

Natomiast protestancka biblistka warszawska Kalina Wojciechowska w artykule Wbrew zwyczajom i tradycji. Interpretacja metafory „Nie jest dobrze zabierać chleb dzieci i rzucać pieskom” (Mk 7,27b) z perspektywy Syrofenicjanki (CT 85[2015] nr 3, s. 33-48) w ciekawy sposób interpretuje tytułowy tekst z perspektywy kobiecej, domowej, w której karmienie piesków pod stołem jest czymś pozytywnym (tamże, s. 44).

Z kolei Dariusz Iwański z Torunia w artykule Gtuchoniemy poganin z Dekapolu? (Mk 7,31-37) (CT 78[2008] nr 3, s. 29-44) wbrew opinii większości biblistów broni tezy, że tytułowa scena nie miała miejsca w Dekapolu, ale już w Galilei (tamże, s. 33, 43). Choć podobne poglądy znaleźć można we wcześniejszej międzynarodowej literaturze przedmiotu, docenić należy odwagę myślenia polskiego biblisty.

Franciszek Mickiewicz z Ołtarzewa w artykule Namaszczenie Jezusa Duchem Świętym na proroka według Łk 3,21-22; 4, 18; Dz 10, 38 (CT 77[2007] nr 1, s. 69-88) analizuje tytułowe teksty nowotestamentalne i podkreśla prorocki charakter misji Jezusa w dwudziele Łukaszowym (tamże, s. 88), nie stawiając jednak pytania o funkcję tego motywu w teologii Łukaszowej. 
Problematyki relacji pomiędzy chrześcijaństwem a judaizmem dotyka artykuł Zdzisława Żywicy Odpowiedzialność Żydów jerozolimskich za utrate godności synów Abrahama i łaski usprawiedliwienia w Jezusie (Dz 13,13-41) (CT 78[2008] nr 2, 31-49). Olsztyński biblista analizuje odnośny tekst Łukaszowy, nie badając go jednak na tle teologii Pawłowej.

Dorota Muszytowska z Warszawy w obszernym artykule Rola etosu $w$ retoryce narracji o pobycie Pawta w Atenach (Dz 17, 16-34) (CT 83[2013] nr 3, s. 35-65) analizuje perswazyjne cechy tytułowego tekstu, stawiając tezę, że kształtuje on specyficzny chrześcijański etos u swych odbiorców. Narrator wspiera przy tym odbiorcę w dokonaniu właściwego wyboru proklamowanego etosu, który powinien być zgodny z etosem Pawłowym (tamże, s. 65).

Do problematyki relacji między chrześcijaństwem a judaizmem powraca również Dariusz Kotecki w artykule Kościół a Synagoga w tradycji Janowej (CT 78[2008] nr 2, s. 11-30). Toruński biblista przyjmuje niegdyś popularną tezę, że Janowe „wyłączenie z Synagogi” odnosiło się do żydowskiego Birkat ha-Minim (tamże, s. 18-20), choć teza ta jest już dziś mocno dyskusyjna, jak zaznacza Mirosław Wróbel w artykule Znaczenie formuły „Birkat ha-Minim” w procesie rozdziału Synagogi od Kościoła (CT 78[2008] nr 2, s. 65-80).

Janusz Kręcidło z Warszawy w artykule Tożsamość Umiłowanego Ucznia w czwartej Ewangelii (CT 78[2008] nr 3, s. 45-58), wbrew opinii wpływowego biblisty amerykańskiego R. E. Browna, broni tezy, że Umiłowany Uczeń w J 21,7 jest jednym z dwóch anonimowych uczniów, a więc - wbrew tradycyjnej identyfikacji - nie jest jednym z synów Zebedeusza (tamże, s. 55-56). Polski biblista miał więc odwagę w uzasadniony sposób sprzeciwić się poglądom uznanych autorytetów.

$\mathrm{W}$ artykule Człowiek i jego religia $w$ soteriologicznej ocenie Pawła Apostoła (CT 81[2011] nr 1, s. 41-60) Zdzisław Żywica z Olsztyna w skrótowy sposób omawia soteriologię św. Pawła, nie wchodząc w kwestię zróżnicowania koncepcji soteriologicznych w poszczególnych listach apostoła (zwłaszcza Listu do Rzymian i Listu do Filipian). 
W dość obszernym artykule Metafora budowania $w$ listach św. Pawła (CT 77[2007] nr 2, s. 5-29) Andrzej Najda z Łomży analizuje tytułową przenośnię, nie dostrzegając jednak jej ukrytej retorycznej funkcji w kontekście rywalizacji Pawła z Apollosem (tamże, s. 13-17).

Franciszek Mickiewicz z Warszawy w artykule Znaczenie sumienia oraz prawa wypisanego w sercu wedtug Rz 2, 12-16 (CT 83[2013] $\mathrm{nr}$ 2, s. 77-96) przeprowadza egzegezę tytułowego tekstu, nie formułując jednak końcowych konkluzji.

Marcin Kowalski w obszernym artykule ,, Wiedza wbija w pyche, miłość zaś buduje” (1Kor 8,1b). Pawłowa reguła życia wspólnoty wedtug 1Kor 8,1 - 11,1 (CT 85[2015] nr 2, s. 31-67) stosuje do tytułowego tekstu metodę analizy retorycznej w wersji wypracowanej przez profesora Biblicum J.-N. Alettiego, a następnie wyciąga z tej analizy wnioski teologiczne. Tekst lubelskiego biblisty jest kolejnym przykładem przenikania do polskiej biblistyki metod wypracowanych na rzymskich uczelniach papieskich.

Problematykę pneumatologiczną podejmuje z kolei Rajmund Pietkiewicz w artykule „,Słowo madrości” i ,słowo poznania” (1Kor 12,8). Studium teologiczno-praktyczne o biblijnych $i$ współczesnych charyzmatach (CT 84[2014] nr 1, s. 49-66). Wrocławski biblista dotyka w nim problemu bardzo istotnego w kontekście współczesnego rozwoju wspólnot charyzmatycznych. Stawia tezę, że popularne w tych wspólnotach „słowo poznania” nie odpowiada treściowo jego nowotestamentalnemu odpowiednikowi, lecz przypomina raczej dar proroctwa. Poza tym, w odróżnieniu od dzisiejszych psychologicznych interpretacji „słowa poznania”, nowotestamentalny dar logos gnōseōs ma charakter zdecydowanie chrystocentryczny (tamże, s. 66).

W artykule Pawłowa próba uzdrowienia pograżonego $w$ kryzysie Kościoła korynckiego w świetle 2Kor 1, 18-22 (CT 84[2014] nr 1, s. 31-48) Zdzisław Żywica z Olsztyna omawia historyczne i teologiczne aspekty Pawłowych relacji z Koryntianami, zwracając uwagę na rolę obecności Ducha dla tożsamości chrześcijan (tamże, s. 46-47).

Z kolei Dariusz Piskorski z Płocka w artykule Preegzystencja Chrystusa czy prehistoria Adama? Adamiczna wyktadnia Flp 2, 6-11 w ujęciu J.D.G. Dunna (CT 80[2010] nr 2, s. 21-37) analizuje tytułowe 
zagadnienie, krytykując hipotezę znanego brytyjskiego biblisty jako metodologicznie nieuzasadnioną (tamże, s. 36-37).

Janusz Wilk z Katowic w artykule Charakterystyka Tymoteusza w 1Tes 3,2 (CT 84[2014] nr 3, s. 19-30) podchodzi do analizowanego zagadnienia z punktu widzenia semantyki tekstu. Dość jednorodnie, bez krytycznych rozróżnień, korzysta przy tym z danych zarówno Pawłowego listu, jak i po-Pawłowych Listów Pasterskich i Dziejów Apostolskich (tamże, s. 30).

Natomiast Zdzisław Żywica w artykule Znaczenie ifunkcja tò

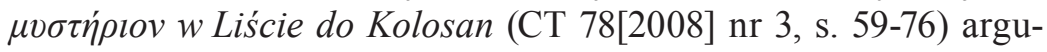
mentuje, że treścią tytułowego określenia jest Jezus Chrystus (tamże, s. 74), nie dostrzegając w wystarczający sposób powiązania tego określenia z głoszeniem Ewangelii wśród pogan (Kol 1,27).

W artykule Istota ewangelizacji w świetle orędzia 1Tm 1,12-17 (CT 83[2013] nr 1, s. 57-69) Stanisław Haręzga z Przemyśla przeprowadza analizę tytułowego tekstu, a następnie dokonuje próby jego aktualizacji, zwracając się do odbiorców przez określenia typu „każdy z nas” i „my” (tamże, s. 67-69).

$\mathrm{Z}$ kolei Artur Malina z Katowic w artykule Teologia światyni i ofiary w Liście do Hebrajczyków (CT 79[2009] nr 2, s. 51-63) podchodzi do tytułowego zagadnienia głównie od strony semantycznej, analizując zawarte w Hbr 8-9 określenia i zwroty odnoszące się do świątyni.

Artykuł Tomasza Jelonka Doskonałość odnowionego przymierza wedtug Listu do Hebrajczyków (CT 78[2008] nr 2, s. 51-63) dotyka podobnej problematyki. Krakowski biblista broni przy tym rzadko przyjmowanej we współczesnej biblistyce hipotezy, że autorem Listu do Hebrajczyków jest św. Łukasz (tamże, s. 52, 58). Warto docenić odwage polskiego naukowca, który szuka własnej drogi myślenia, wychodząc poza kopiowanie poglądów współczesnego biblistycznego mainstreamu.

$\mathrm{Z}$ kolei w artykule Retoryczna deliberacja w Liście Jakuba 2, 14-16 (CT 83[2013] nr 2, s. 97-112) Dorota Muszytowska dokonuje analizy tego bardzo kontrowersyjnego w teologii chrześcijańskiej tekstu z punktu widzenia analizy retorycznej. Warszawska biblistka 
w dość standardowy sposób opisuje zastosowane w tekście figury retoryczne itp. Nie wchodzi przy tym w bardziej subtelne kwestie pozornie anty-Pawłowego wykorzystania tekstów Pawłowych, ambiwalencji pytań/twierdzeń na temat Abrahama i Rachab w Jk 2,21.25, problematyczności exemplum pogańskiej prostytutki w rzekomo judeochrześcijańskim liście itp.

W artykule Funkcja metafor militarnych w Pierwszym Liście Piotra (CT 82[2012] nr 2, s. 59-70) Janusz Kręcidło z Warszawy analizuje odnośne fragmenty tytułowego listu i zawarte w nich metafory, nie podejmując bardziej ogólnego problemu obecności tych metafor właśnie w Liście Piotra (i w Corpus Paulinum), a nie np. w retorycznie i literacko pokrewnym do niego Liście Jakuba.

$\mathrm{Z}$ kolei w artykule Formuła „Bóg jest miłościa” w $1 \mathrm{~J} \mathrm{4,8.16} \mathrm{i} \mathrm{jej}$ recepcja w pierwszej encyklice Benedykta XVI (CT 77[2007] nr 3, s. 63-79) Stanisław Haręzga stosuje dość rzadko spotykane w polskiej biblistyce podejście badawcze oparte na analizie historii oddziaływania tekstu (Wirkungsgeschichte), ograniczając je jednak do niedawno opublikowanej encykliki nowego papieża, która podkreśla rolę wertykalnego wymiaru miłości - do Boga. Zaproponowane przez przemyskiego biblistę podejście świadczy w każdym razie o silnym związku polskiej biblistyki z aktualnym nauczaniem Kościoła.

Z kolei Piotr Ostański z Poznania w artykule Propozycja nowej interpretacji Ap 3,14 (CT 85[2015] nr 2, s. 69-81) formułuje oryginalną hipotezę, że imię „Amen” w Ap 3,14 należy czytać jako „A-Men” i tłumaczyć „nie Men”, interpretując je jako opozycję dla anatolijskiego bóstwa Mena (tamże, s. 75-80).

W nowotestamentalnej części artykułu Jezus Chrystus - Arcykapłan Nowego Przymierza (CT 80[2010] nr 3, s. 7-34) Waldemar Chrostowski omawia teksty Nowego Testamentu, w których pojawiają się wyraźne odniesienia do kapłaństwa. Warszawski biblista jedynie mimochodem wspomina przy tym o aluzjach do kapłaństwa w tekstach Pawłowych (tamże, s. 24, 32), nie wchodząc także w kwestię kapłaństwa apostołów w Dziejach Apostolskich.

Również w nowotestamentalnej części artykułu Niewidomi w Piśmie Świętym (CT 82[2012] nr 2, s. 5-22) ten sam autor omawia odnośne 
teksty Nowego Testamentu, nie analizując kwestii możliwego symbolicznego znaczenia dwuetapowego uzdrowienia w Mk 8,22-26, imienia Bartymeusza syna Timajosa itp. (tamże, s. 16-17).

W zeszycie CT 83(2013) nr 4 po raz pierwszy pojawia się Biuletyn biblijny, redagowany przez Barbarę Strzałkowską (tamże, s. 175-192). Choć biuletyny z innych specjalności teologii pojawiały się w czasopiśmie od wielu dziesiątek lat, na biuletyn biblijny trzeba było czekać aż do 2013 r. Włączenie go do czasopisma świadczy zatem o uznaniu rangi, jaką badania biblijne mają wśród innych obszarów badań teologicznych, skoro według konstytucji soborowej studium Pisma Świętego powinno być jakby duszą świętej teologii (DV 24).

Wiele artykułów publikowanych w „Collectanea Theologica” w omawianym okresie ma więc charakter publikacji posympozjalnych, dotyczących recepcji określonej księgi starotestamentalnej w Nowym Testamencie. Wpłynęło to pozytywnie na pewne uporządkowanie omawianej w periodyku tematyki egzegetycznej i teologiczno-biblijnej.

\section{Czas powszechnego dostępu w wersji elektronicznej (2015-2020)}

Od numeru 4/2015 czasopismo „Collectanea Theologica” jest powszechnie dostępne na platformie elektronicznej w systemie open access. Wpływa to na zwiększenie zasięgu oddziaływania publikowanych w nim artykułów. Pośrednio powinno to także wpływać na podniesienie ich poziomu merytorycznego i formalnego.

W artykule Księga Amosa i listy Pawłowe w Dziejach Apostolskich (CT 85[2015] nr 4, s. 125-144) Bartosz Adamczewski, wbrew opinii wielu współczesnych biblistów, broni tezy o Łukaszowym wykorzystaniu listów Pawła, zwłaszcza Listu do Galatów. Warszawski biblista traktuje więc wykorzystanie włożonego w usta Jakuba cytatu z Am 9,11-12 LXX w Dz 15,16-18, z zagadkowo dodanym elementem „znania” od wieków w Dz 15,18, jako element kreatywnej przeróbki tekstu Ga 2,9, z jego motywem Jakubowego „uznania” łaski danej Pawłowi (tamże, s. 136). 
Ten sam autor w artykule Intertekstualna funkcja cytatu z Ksiegi Ozeasza w Mateuszowej Ewangelii Dzieciństwa (CT 86[2016] nr 4, s. 125-138) stawia nowatorską w międzynarodowej biblistyce tezę o systematycznym Mateuszowym wykorzystaniu Łukaszowych Dziejów Apostolskich. Warszawski biblista wyjaśnia nietypową formę cytatu z Oz 11,1 w Mt 2,15 i jego funkcję ,cytatu refleksyjnego" jako efekt aluzyjnego dostosowania go do tekstu Dz 3,22-26 (tamże, s. 135-137).

$\mathrm{Z}$ kolei Adam Kubiś w artykule „Miłości pragnę, nie krwawej ofiary”. Relektura Oz 6,6 w Ewangelii wedtug św. Mateusza (CT 86[2016] nr 4, s. 103-124) zabiera głos we współczesnej dyskusji nad wersją Starego Testamentu, z której korzystał Mateusz. Lubelski biblista broni tezy o wykorzystaniu przez Mateusza tekstu hebrajskiego Księgi Ozeasza (tamże, s. 114).

Natomiast w artykule Aluzje z Księgi Sofoniasza w Nowym Testamencie? (CT 87[2017] nr 4, s. 107-124) Dariusz Kotecki z Torunia stwierdza, że zamiast o obecności aluzji do Sofoniasza lepiej mówić o różnych możliwych kategoriach jego wpływu na pisma Nowego Testamentu (tamże, s. 123-124).

Artur Malina z Katowic w artykule Dlaczego List do Hebrajczyków przypomina o pragnieniach patriarchów? (CT 88[2018] nr 4, s. 125-138) analizuje tekst Hbr 11 na jego tle starotestamentalnym w zaproponowanych w dokumencie PKB o ludzie żydowskim i jego świętych Pismach w Biblii chrześcijańskiej w kategoriach ciągłości i nieciągłości, wskazując na pewne braki tego dokumentu (tamże, s. 125-126). Świadczy to o uważnej, a jednocześnie nie bezkrytycznej recepcji dokumentów PKB w polskiej biblistyce.

W obszarze badań nad samym Nowym Testamentem Zdzisław Żywica z Olsztyna w artykule Eklezja Mateusza - eschatologiczna „,Resztą Izraela”? (CT 86[2016] nr 1, s. 25-40) odpowiada na tytułowe pytanie twierdząco, widząc w tym rozwiązanie szeroko dyskutowanego obecnie problemu stosunku Mateusza do judaizmu i do Izraela.

Kazimierz Pierzchała z Warszawy w artykule Zamieszkanie Stowa Wcielonego (CT 88[2018] nr 1, s. 73-89) analizuje Janowy Prolog na tle pojęć starotestamentalnych, trafnie wiążąc obraz ,rozbicia 
namiotu" w J 1,14 z opisywanym m.in. w Za 8,3 zamieszkaniem w Jeruzalem, ale nie podając żadnej literatury przedmiotu na ten temat (tamże, s. 75).

W artykule Nowe życie uczniów Jezusa w Ewangelii Jana (CT 88[2018] nr 2, s. 5-16) Dawid Ledwoń z Katowic w ciekawy sposób opisuje tytułową Janową koncepcję nowego życia, choć nigdzie w czwartej Ewangelii określenie takie się nie pojawia. Stosuje przy tym elementy analizy narracyjnej.

Adam Kubiś z Lublina w obszernym artykule Temat stworzenia w Ewangelii Janowej (CT 88[2018] nr 3, s. 5-38) argumentuje zaś, że tytułowy temat tworzy inclusio w czwartej Ewangelii, gdyż obecny jest na początku (J 1,1-18) i na końcu (J 20,22) narracji Janowej (tamże, s. 36). Nie pokazuje przy tym (tamże, s. 25-26), że ta ostatnia teza jest dość dyskusyjna, gdyż leksykalnie J 20,22 bliższy jest tekstowi Ez 37,9 niż Rdz 2,7.

Z kolei Waldemar Rakocy z Lublina w artykule Pytanie o klucz do teologii apostoła Pawła (CT 86[2016] nr 1, s. 41-60) argumentuje, że tym poszukiwanym przez wielu biblistów kluczem jest koncepcja nowego stworzenia w Chrystusie, która dobrze ujmuje nowość życia w Chrystusie zarówno dla Żydów, jak i dla pogan (tamże, s. 58-59).

W artykule ,Obrzezany” Grek $i$,prawdziwy” Żyd w świetle $R z$ 1,18 - 3,20 (CT 87[2017] nr 1, s. 25-48) Zdzisław Żywica z O1sztyna omawia główne idee tego kontrowersyjnego tekstu, argumentując, że jego głównym orędziem jest wykazanie nie tyle powszechnej grzeszności ludzi, ile ich usprawiedliwienia w Chrystusie (tamże, s. 47).

Ten sam autor w artykule Prawość apostoła $w$ świetle $R z$ 9,1-5 (CT 87[2017] nr 3, s. 5-23) przeprowadza egzegezę tytułowego tekstu, opierając się na wypracowanej przez J-N. Alettiego z Biblicum metodzie analizy retorycznej. Argumentuje przy tym, że zestawienie trzech świadectw w Rz 9,1 odpowiada biblijnej tradycji prawnej o konieczności powołania dwóch albo trzech świadków (tamże, s. 20-21).

Również w artykule Rozumna stużba a odnowiony umyst $w$ świetle $R z$ 12,1-2 (CT 88[2018] nr 1, s. 5-21) Żywica stosuje tę samą metodę analizy tekstu, stwierdzając, że tytułowa służba to służba 
ewangeliczna (tamże, s. 20). Nie wchodzi przy tym w problematykę liturgicznego znaczenia tytułowego tekstu i jego odniesienia do Eucharystii.

Z kolei Janusz Wilk z Katowic w artykule Personalia w Drugim Liście do Tymoteusza 4,9-15 (CT 87[2017] nr 1, s. 49-74) nie rozstrzyga kontrowersyjnej kwestii autorstwa tego tekstu. Zauważa natomiast, że negatywna charakteryzacja niektórych wymienionych w nim współpracowników Pawła pokazuje, że konieczna jest osobista wiary w Chrystusa, a nie tylko przebywanie z apostołem (tamże, s. 73).

Franciszek Mickiewicz SAC z Warszawy w artykule Działalność misjonarska św. Piotra poza Palestyna w świetle literatury nowotestamentowej (CT 89[2019] nr 3, s. 85-109) broni hipotezy o obecności Piotra w Koryncie (tamże, s. 107-108) wbrew stanowisku wielu współczesnych badaczy, m.in. K. Romaniuka (CT 46[1976] fasc. spec., s. 123-125), do którego jednak w swoim artykule się nie odnosi.

Ten sam autor w artykule Główne tematy teologiczne Drugiego Listu św. Piotra (CT 88[2018] nr 1, s. 23-42) stosuje do analizy tytułowego tekstu znaną, choć metodologicznie problematyczną metodę mirror reading, starając się odtworzyć idee oponentów autora Drugiego Listu Piotra. Nie wchodzi natomiast w problematykę funkcji systematycznego a jednocześnie krytycznego wykorzystania Listu Judy w Drugim Liście Piotra, a z drugiej strony bardzo pozytywnego odniesienia Drugiego Listu Piotra do listów Pawła. Przeprowadzona przez warszawskiego biblistę analiza teologii tego listu Piotra prowadzona jest więc nieco w izolacji od jej ewidentnego intertekstualno-ideowego kontekstu.

Tematyki Piotrowej dotyczy również artykuł Anny Rambiert-Kwaśniewskiej Matżeństwa mieszane i jak sobie $w$ nich radzić wedtug ,tablicy matżeńskiej” IP 3,1-7. Za czy przeciw tradycji Pawtowej? (CT 88[2018] nr 1, s. 43-71). Wrocławska biblistka zwraca w nim uwagę, że aktualizacja tytułowego tekstu w odniesieniu do kobiet musi odbywać się w kluczu poświęcającej siebie miłości, a nie akceptacji przemocy domowej (tamże, s. 69-70).

W najnowszym okresie istnienia „Collectanea Theologica” spora część publikowanych w nim artykułów nowotestamentalnych była 
pokłosiem organizowanych na UKSW konferencji biblijnych, poświęconych recepcji poszczególnych ksiąg Starego Testamentu w Nowym. Fakt, że były to konferencje ogólnopolskie, pozytywnie wpływał na szeroką reprezentację różnych środowisk naukowych w publikacjach na łamach periodyku. Pozostaje mieć nadzieję, że to otwarcie na działalność różnych ośrodków teologicznych oraz nieustanne podnoszenie poziomu merytorycznego i formalnego będzie cechować nowotestamentalne publikacje na łamach „Collectanea Theologica” także w przyszłości.

$$
* * *
$$

Obecność publikacji dotyczących Nowego Testamentu miała w ciągu stu lat istnienia „Collectanea Theologica” (1920-2020) bardzo różny charakter. W okresie przedwojennym i we wczesnych latach powojennych zamieszczane w czasopiśmie artykuły nowotestamentalne miały dużo elementów apologetycznych. Związane to było z potrzebą dania odpowiedzi przedwojennym ideom laickim, a następnie $\mathrm{z}$ profilem czasopisma wydawanego w powojennym środowisku warszawskim, pozostającym pod dużym wpływem apologety ks. Wincentego Kwiatkowskiego. W owym okresie artykuły nowotestamentalne miały jednak niejednokrotnie znaczną objętość, nierzadko będąc częścią większych rozpraw naukowych.

W okresie posoborowym artykuły nowotestamentalne stały się generalnie krótsze i nastawione bardziej pastoralnie. Ich poziom merytoryczny był bardzo różny - od bardzo wnikliwych studiów naukowych, proponujących oryginalne rozwiązania trudnych problemów egzegetycznych, do omawiania tekstów własnymi słowami w celu wyciągnięcia z nich jakichś wniosków teologicznych.

Od czasu objęcia w 1990 r. funkcji redaktora naczelnego „Collectanea Theologica” przez ks. Waldemara Chrostowskiego wyraźnie wzrosła liczba publikacji dotyczących stosunku chrześcijaństwa do judaizmu. Z czasem zmalała, wzrosła natomiast liczba publikacji poświęconych problematyce recepcji Starego Testamentu w Nowym. 
Charakterystyczną cechą artykułów nowotestamentalnych publikowanych w „Collectanea Theologica” jest ich silny związek z dokumentami watykańskimi dotyczącymi Pisma Świętego, a także z metodami analizy teksów biblijnych, wypracowanymi na rzymskich uczelniach papieskich, przy jednoczesnym zachowaniu dość krytycznego stosunku do dorobku biblistyki niemieckojęzycznej. Polscy badacze Nowego Testamentu, publikujący swe prace w „Collectanea Theologica”, generalnie starali się unikać teorii oryginalnych lecz ekstrawaganckich, skupiając swe wysiłki na takim interpretowaniu pism Nowego Testamentu, które buduje wiarę Ludu Bożego.

\section{ks. Bartosz ADAMCZEWSKI}

Słowa kluczowe: Collectanea Theologica; Nowy Testament; biblistyka; metody egzegetyczne; Polska

Keywords: Collectanea Theologica; New Testament; biblical scholarship; exegetical methods; Poland

\section{The Research on the New Testament in "Collectanea Theologica" 1920-2020 \\ Summary}

The articles published in the Polish theological journal "Collectanea Theologica" initially (1920-1965) had significant apologetic characteristics. After the Second Vatican Council (1966-1989), they became more pastorally oriented. Especially in the years 1990-2006, many articles were devoted to the relationship between Christianity and Judaism. Since 2007, the problem of the reception of the Old Testament in the New Testament has become much more prominent. In general, the articles related to the New Testament bear witness to the strong ties of Polish biblical scholarship with the Vatican documents concerning Scripture as well as the exegetical methods elaborated in the pontifical universities and institutes in Rome. On the other hand, the heritage of German biblical scholarship is treated in the New Testament articles published in "Collectanea Theologica" with greater mistrust and criticism. 